\title{
AUTOTUTELA EJECUTIVA Y CONTROL JUDICIAL EN LA ENTRADA EN DOMICILIOS
}

\author{
José Francisco Fernández García \\ Profesor Titular de Derecho Administrativo \\ Universidad de Oviedo
}

\begin{abstract}
RESUMEN
Salvo aspectos muy concretos, el régimen jurídico de la entrada en domicilio debe inferirse de la jurisprudencia y de la praxis judicial, al no existir una regulación acabada en esta materia. El objeto del presente trabajo es llevar a cabo un análisis sistemático de esta cuestión al hilo de los numerosos pronunciamientos emitidos, con el fin de ofrecer una solución práctica y unívoca en relación con los distintos aspectos que aún hoy son objeto de controversia. El propio alcance del concepto constitucional de domicilio o la forma en que ha de recabarse el consentimiento del titular del derecho sirven de presupuestos básicos para abordar el análisis nuclear de este estudio, centrado en determinar el alcance del control que ha de llevar a cabo el órgano judicial competente en garantía del derecho constitucional a la inviolabilidad del domicilio y su afectación a la autotutela ejecutiva de la Administración Pública.
\end{abstract}

Palabras clave: domicilio; garantía jurisdiccional.

\begin{abstract}
Unless specific aspects, the legal regime of entry in domicile must be inferred from the case law and judicial practice, in the absence of regulation on this matter finished yet. The purpose of this study is to carry out a systematic analysis of this question in line with the numerous issued pronouncements, in order to provide a practical and unambiguous solution regarding the various aspects that still today are an object of controversy. The very extent of the constitutional concept of domicile or the form in which there has to be obtained the consent of the holder of the right, used as basic budgets to approach the nuclear analysis of this study focused on determining the scope of the control that has to carry out the judicial competent court in guarantee of the constitutional law to the inviolability of the domicile and its impact on the executive self tutelage of the Public Administration.
\end{abstract}

Key words: domicile; jurisdictional guarantee. 


\section{SUMARIO}

I. El DOMICILIO COMO BIEN JURÍDICO PROTEGIDO: 1. La inviolabilidad del domicilio. 2. El concepto constitucional de domicilio: otros lugares de entrada restringida.II. EL TITULAR DEL DERECHO: 1. La concreción del elemento subjetivo. 2. La emisión del consentimiento y las excepciones a la necesidad de su prestación.-III. LA RESTRICCIÓN DE LA AUTOTUTELA EJECUTIVA DE LA ADMINISTRACIÓN: 1. La intervención judicial como acto de apoderamiento de la Administración. 2. La situación jurídica del acto a ejecutar.-IV. EL CONTROL JUDICIAL DE LA ENTRADA EN DOMICILIOS: 1. El procedimiento para la obtención de la autorización judicial. 2. El alcance del control a efectuar. 3. El recurso contra el auto judicial y la ejecutividad del acto administrativo.-V. CONCLUSIONES.

\section{EL DOMICILIO COMO BIEN JURÍDICO PROTEGIDO}

\section{La inviolabilidad del domicilio}

El artículo 18.2 de la Constitución española proclama que el domicilio es inviolable, precisando, a continuación, que ninguna entrada o registro podrá hacerse en él sin consentimiento del titular o resolución judicial, salvo en caso de flagrante delito.

Dada la ubicación de este artículo en la Carta Magna, la inviolabilidad del domicilio se configura, según advierte la Sentencia de 17 de enero de 2002 del Tribunal Constitucional, como un derecho fundamental, vinculado a la protección de la intimidad personal y familiar, a la que el propio precepto constitucional hace referencia en su apartado primero $^{1}$ :

«La norma constitucional que proclama la inviolabilidad del domicilio y la interdicción de la entrada y registro domiciliario (art. 18.2 CE) constituye una manifestación de la norma precedente (art. 18.1 CE) que garantiza el derecho fundamental a la intimidad personal y familiar (por todas, TC S 136/2000, de 29 May., FJ 3). De esta construcción interrelacionada resulta que la protección de la inviolabilidad domiciliaria tiene carácter instrumental respecto de la protección de la intimidad personal y familiar (TC S 22/1984, de 17 Feb., FJ 5), si bien dicha instrumentalidad no empece a la autonomía que la

\footnotetext{
1 Vid. Sentencia 10/2002, de 17 de enero (Rec. 2829/1994), del Pleno del Tribunal Constitucional. Igualmente, STC 120/2014, de 17 de julio, Rec. 1756/2003; STC 188/2013, de 4 de noviembre, Rec. 3769/2012; STC 150/2011, de 29 de septiembre, Rec. 5125/2003; STC 22/2003, de 10 de febrero, Rec. 4400/1999.
} 
Constitución española reconoce a ambos derechos, distanciándose así de la regulación unitaria de los mismos que contiene el art. 8.1 del Convenio Europeo de Derechos Humanos (en adelante, CEDH; TC S 119/2001), de 24 May., FJ 6)».

Además de actuar como una proyección o plasmación del citado derecho, la inviolabilidad del domicilio es, al mismo tiempo, expresión de la dignidad del ser humano y del respeto que esa condición exige a los poderes públicos.

Desde esta última perspectiva, se puede afirmar, por tanto, que el fundamento del derecho a la inviolabilidad del domicilio se halla, a su vez, en la estrecha relación que mantiene este derecho con la vida privada.

Sostiene así la doctrina que existe entre ambos bienes una relación de medio y fin, de modo que la vida privada es objeto de la protección constitucional que se confiere a la intimidad y, más ampliamente, al conjunto de derechos que contiene el mencionado artículo 18 de la Constitución española ${ }^{2}$.

Particularmente ilustrativa resulta en este punto la Sentencia de 29 de septiembre de 2011 del Tribunal Constitucional, en la que viene a concluirse lo siguiente ${ }^{3}$ :

«En nuestra Constitución no existe un derecho fundamental a la "privacidad" (o a la protección a la vida privada) en sentido amplio, sino unos muy concretos derechos de objeto, pues, más delimitado sobre ámbitos precisos de esa privacidad (art. $18 \mathrm{CE}$ ). Tal derecho a la "privacidad" en sentido amplio, procedente del mundo anglosajón y en especial del Derecho de los Estados Unidos de América, es justamente el reconocido en el art. 8.1 CEDH que, por ello, no puede identificarse por completo con nuestro art. 18.1 y $2 \mathrm{CE}$.

En tal sentido, ha de advertirse que, por lo que se refiere al derecho a la intimidad personal y familiar

2 Vid. M. A. Ruiz López (2011), «Autorización judicial de entrada en el domicilio y potestades administrativas: extensión del ámbito protegido, cuestiones procedimentales y proporcionalidad", Revista de Estudios de la Administración Local y Autonómica, núm. 317, págs. 213-234. Cit. E. EsPín TEMPLADO (1991), «Fundamento y alcance del derecho fundamental a la inviolabilidad del domicilio», Revista del Centro de Estudios Constitucionales, núm. 8.

3 Vid. Sentencia 150/2011, de 29 de septiembre, del Pleno del Tribunal Constitucional (Rec. 5125/2003). 
(art. 18.1 CE), no cabe duda de que la pretensión del constituyente fue proteger el núcleo del derecho a la vida privada, es decir, la intimidad en sentido estricto (a diferencia del concepto amplio que se utiliza en el art. 8.1 CEDH, y que corrobora el Tribunal Europeo de Derechos Humanos en su interpretación de este precepto). Tal entendimiento se deriva no solo del propio término empleado en el art. 18.1 CE (intimidad), sino que tiene una lógica conexión con otros preceptos constitucionales (así, en virtud del art. 20.4 CE, con las libertades de expresión e información). En cuanto al libre desarrollo de la personalidad (que se trae a colación como otro componente del derecho a la vida privada por la doctrina del Tribunal Europeo de Derechos Humanos en relación con el art. 8.1 CEDH) baste recordar que no se concibe en nuestra Constitución como un derecho fundamental, sino como un principio que se erige en uno de los fundamentos del orden constitucional (art. 10.1 CE).

A similares conclusiones cabe llegar en cuanto al derecho a la inviolabilidad del domicilio (art. 18.2 CE), cuyo contenido y alcance en nuestra Constitución es bastante más limitado que el derecho al respeto del domicilio contemplado en el art. 8.1 CEDH y en la jurisprudencia del Tribunal Europeo de Derechos Humanos que interpreta este precepto. En nuestra Constitución se lesiona este derecho fundamental cuando se accede a la morada sin el consentimiento de su titular o sin autorización judicial (salvo el caso de delito flagrante)».

Por todo ello, la inviolabilidad del domicilio se configura como un derecho fundamental de la persona, establecido para garantizar el ámbito de privacidad de ésta, dentro del espacio limitado que la propia persona elige y que tiene que caracterizarse precisamente por quedar exento o inmune a las invasiones o agresiones exteriores, de otras personas o de la autoridad pública ${ }^{4}$.

En todo caso, la inviolabilidad del domicilio, como es regla general a cualquier derecho, no tiene un carácter absoluto, pues cede ante valores superiores en conflicto, como el bien común, que debe prevalecer frente al interés particular que ostenta el titular del mismo.

\footnotetext{
4 Vid. STC 22/1984.
} 
En este sentido la propia norma constitucional sitúa al juez ordinario como primer garante de este derecho y, a la vez, impone una clara restricción en la autotutela ejecutiva de la Administración Pública, que, como indica la Sentencia del TSJ de Cantabria de 3 de julio de 2014, opera de manera consustancial con el principio de eficacia administrativa del artículo 103.1 de la Constitución española, y aparece así preventivamente mediatizada a través de la intervención de los órganos jurisdiccionales ${ }^{5}$ :

«Es conveniente centrar el alcance y finalidad del singular procedimiento judicial del art. 8.5 LJCA (en la actualidad art. 8.6 LJCA ) sobre "autorización de entrada en domicilios y restantes lugares cuyo acceso requiera el consentimiento de su titular, siempre que ello proceda para la ejecución forzosa de actos de la Administración pública", habiendo tenido ocasión de pronunciarse el Tribunal Constitucional y el Tribunal Supremo, en el sentido de que se trata de conciliar a través de este medio procesal el respeto al derecho fundamental a la inviolabilidad del domicilio, con la ejecutoriedad de los actos administrativos que es consecuencia del principio de autotutela administrativa en su vertiente ejecutiva (Sentencia Tribunal Supremo de 27/09/97)».

2. El concepto constitucional de domicilio: otros lugares de entrada restringida

Son diversas las definiciones que el Ordenamiento jurídico ofrece del concepto de domicilio, tanto en el ámbito civil como por parte de la legislación administrativa.

Así, el artículo 40 del Código Civil dispone que para el ejercicio de los derechos y el cumplimiento de las obligaciones civiles, el domicilio de las personas naturales es «el lugar de su residencia habitual».

En sentido similar, el artículo 48 de la Ley General Tributaria establece que el domicilio fiscal es «el lugar de localización del obligado tributario en sus relaciones con la Administración tributaria».

5 Vid. Sentencia del TSJ de Cantabria 281/2014, de 3 de julio (Rec. 68/2014). En la doctrina, vid. F. LóPEz RAMÓN (1988), "Límites constitucionales a la autotutela administrativa», $R A P$, núm. 115, págs. 88 y ss; J. M. Macías CASTAÑo (2001), «El desahucio administrativo. La problemática de su ejecución: la entrada en un domicilio y la jurisprudencia constitucional», Seminari.fmc.cat., pág. 11; A. Nieto García (1987), «Actos administrativos cuya ejecución precisa una entrada domiciliaria», $R A P$, núm. 112, pág. 56. 
El concepto constitucional de domicilio, inherente al citado artículo 18.2 de la Constitución española, es, sin embargo, un concepto distinto, tanto por su carácter finalista como por el amplio alcance que la jurisprudencia llega a atribuir al mismo ${ }^{6}$.

$\mathrm{Al}$ respecto, el Tribunal Supremo ha definido el domicilio como «el lugar destinado a la habitación de una persona $»^{7}$, equiparándolo al concepto de morada, al que alude el artículo 554.2. ${ }^{\circ}$ de la Ley de Enjuiciamiento Criminal.

Por su parte, el Tribunal Constitucional concibe ese lugar como «el espacio en el cual el individuo vive sin estar sujeto necesariamente a los usos y convenciones sociales y ejerce su libertad más íntima»; o aquel que, en definitiva, sirve para «el ejercicio de las funciones vitales más características de la intimidad ${ }^{8}$, excluyéndose de esa definición, en todo caso, a los espacios abiertos, que, por sus propias características, nunca podrían ser considerados aptos para desarrollar en ellos vida privada ${ }^{9}$.

Al respecto, la propia Sentencia de 17 de enero de 2002 del Tribunal Constitucional indica ${ }^{10}$ :

«Si, como hemos declarado de forma reiterada, el derecho a la intimidad personal y familiar (art. 18.1 CE) tiene por objeto la protección de un ámbito reservado de la vida de las personas excluido del conocimiento de terceros, sean éstos poderes públicos o particulares, en con-

\footnotetext{
6 Vid. V. FAIRÉn GuILlÉN (1993), «Algunas ideas básicas sobre la “entrada y registro en domicilio" (del artículo 21 de la ley 1/1992, de protección de la seguridad ciudadana, de 21 de febrero)», Revista de Derecho Procesal, núm. 1, págs. 11-60; J. FERnández-Corredor SÁNCHEZ-Diezma (2009), «Entrada a domicilio. Medida administrativa», CEFLegal: Revista Práctica de Derecho. Comentarios y casos prácticos, núm. 103, pág. 175; A. FríAs LóPEz (2000), «Las autorizaciones judiciales de entrada en domicilio", Revista Jurídica de la Comunidad de Madrid, núm. 6, págs. 29-64.

7 Vid. STS de 24 febrero 2010, Rec. 1432/2009; STS de 26 marzo 2007, Rec. 1711/2003; STS de 23 septiembre 1997, Rec. 2169/1996; STS de 4 noviembre 1996, Rec. 956/1994. Vid. J. M. Macías CAstaño (2001), «El desahucio administrativo: la problemática de su ejecución: la entrada en un domicilio y la jurisprudencia constitucional», Revista Española de Derecho Administrativo, núm. 127, págs. 489-517; J. SÁNCHEZ MELGAR (2004), «La entrada y registro en domicilio de particulares: análisis doctrinal y jurisprudencial», en Dogmática y ley penal: libro homenaje a Enrique Bacigalupo, coords. José Miguel ZugaLdía EsPINAR y Jacobo López BARJA DE QUIROGA, vol. 2, ISBN 84-9768-101-0, págs. 1433-1460.

8 Vid. STC 199/2013, de 5 de diciembre, Rec. 9530/2005; STC 188/2013, de 4 de noviembre, Rec. 3769/2012; STC 176/2013, de 21 de octubre, Rec. 1783/2010; STC 92/2013, de 22 de abril, Rec. 4596/2011. Vid J. F. LóPEZ DE HonTANAR SÁNCHEz (2008), «La autorización de entrada en domicilio para la ejecución de actos administrativos», en Estudios Jurídicos. PALOmo Herrero, y (2004), "La diligencia de entrada y registro en domicilio», en Homenaje a don Eduardo Font Serra, tomo II, Eduardo FonT SERRA (aut.), vol. 2, págs. 1849-1880.

9 Vid. J. J. HeRnáNDEZ Domínguez (2012), Supuestos constitucionales que posibilitan la entrada y registro en domicilio, Lex Nova, pág. 2.

10 Ibidem, Sentencia 10/2002, de 17 de enero (RTC 2002\10).
} 
tra de su voluntad (por todas, SSTC 144/1999, de 22 de julio [RTC 1999, 144], F. 8; 119/2001, de 24 de mayo, F. 5), el derecho a la inviolabilidad del domicilio protege un ámbito espacial determinado, el "domicilio", por ser aquel en el que los individuos, libres de toda sujeción a los usos y convenciones sociales, ejercen su libertad más íntima, siendo objeto de protección de este derecho tanto el espacio físico en sí mismo considerado, como lo que en él hay de emanación de la persona y de su esfera privada (SSTC 22/1984, de 17 de febrero, F. 5; 94/1999, de 31 de mayo [RTC 1999, 94], F. 5; y 119/2001, de 24 de mayo, F. 6).

La Constitución no ofrece una definición expresa del domicilio como objeto de protección del art. 18.2 CE. Sin embargo, este Tribunal ha ido perfilando una noción de domicilio de la persona física cuyo rasgo esencial reside en constituir un ámbito espacial apto para un destino específico, el desarrollo de la vida privada. Este rasgo, que ha sido señalado de forma expresa en Sentencias recientes (SSTC 94/1999, de 31 de mayo, F. 4; 283/2000, de 27 de noviembre [RTC 2000, 283], F. 2), se encuentra asimismo comprendido en las declaraciones generales efectuadas por este Tribunal sobre la conexión entre el derecho a la inviolabilidad domiciliaria y el derecho a la intimidad personal y familiar, así como en la delimitación negativa que hemos realizado de las características del espacio que ha de considerarse domicilio y de la individualización de espacios que no pueden calificarse de tal a efectos constitucionales.

Con carácter general, como acabamos de recordar, hemos declarado que "el domicilio inviolable es un espacio en el cual el individuo vive sin estar sujeto necesariamente a los usos y convenciones sociales y ejerce su libertad más íntima. Por ello, a través de este derecho no sólo es objeto de protección el espacio físico en sí mismo considerado, sino lo que en él hay de emanación de la persona y de esfera privada de ella" (SSTC 22/1984, de 17 de febrero, F. 5; 137/1985, de 17 de octubre [RTC 1985, 137], F. 2; 69/1999, de 26 de abril [RTC 1999, 69], F. 2; 94/1999, de 31 de mayo, F. 5; 119/2001, de 24 de mayo, FF. 5 y 6). 
A esta genérica definición hemos añadido una doble consecuencia para el concepto constitucional de domicilio, extraída del carácter instrumental que la protección de la inviolabilidad domiciliaria presenta en la Constitución respecto del derecho a la intimidad personal y familiar, y deducida también del nexo indisoluble que une ambos derechos: en primer término, que "la idea de domicilio que utiliza el art. 18 de la Constitución no coincide plenamente con la que se utiliza en materia de Derecho privado y en especial en el art. 40 del Código Civil como punto de localización de la persona o lugar de ejercicio por ésta de sus derechos y obligaciones"; en segundo lugar, que el concepto constitucional de domicilio tiene "mayor amplitud que el concepto jurídico privado o jurídico-administrativo" (SSTC 22/1984, de 17 de febrero, F. 2; 94/1999, de 31 de mayo, F. 5), y no "admite concepciones reduccionistas [... como las] que lo equiparan al concepto jurídico-penal de morada habitual o habitación" (STC 94/1999, de 31 de mayo, F. 5)».

Desde esa base dogmática, se aprecia como a la hora de determinar la posible existencia de un domicilio resulta en cierto modo irrelevante cuál sea la ubicación o configuración física de ese lugar; de modo que cualquier infravivienda - como podría ser una chabola o, incluso, una cueva- puede llegar a obtener esa calificación.

Igualmente, en muchos casos resultará indiferente que estemos ante un bien de carácter inmueble o mueble, habiendo recibido la dicha consideración jurídica desde una tienda de campaña a un coche o una embarcación, utilizados todos ellos, de forma circunstancial, como vivienda ${ }^{11}$.

A la hora de atribuir a un determinado espacio la condición de domicilio, tampoco resulta determinante la intensidad o periodicidad con la que se desarrolle la vida privada en ese lugar, por lo que, igual-

11 Vid. V. FAIRÉn GuILLÉN (1993), «Algunas ideas básicas sobre la “entrada y registro en domicilio" (del artículo 21 de la ley 1/1992, de protección de la seguridad ciudadana, de 21 de febrero)", Revista de Derecho Procesal, núm. 1, págs. 11-60; J. FERnÁNDEZ-CoRREdor SÁNCHEZ-DiEZMA (2009), «Entrada a domicilio. Medida administrativa», CEFLegal: Revista Práctica de Derecho. Comentarios y casos prácticos, núm. 103, pág. 175; A. FRÍAs LóPEZ (2000), «Las autorizaciones judiciales de entrada en domicilio", Revista Jurídica de la Comunidad de Madrid, núm. 6, págs. 29-64; J. J. QueRALT (1990), «La inviolabilidad domiciliaria y los controles administrativos. Especial referencia a las empresas», Revista Española de Derecho Constitucional, núm. 30, septiembre-diciembre, pág. 53; J. M. RoJí BuQueRAs (2000), El derecho a la inviolabilidad del domicilio y la actuación de los órganos de la Inspección de los Tributos. Un estudio a propósito de la nueva Ley Jurisdiccional 29/1998, de 13 de julio, Impuestos, Ed. La Ley, pág. 6. 
mente, serán objeto de protección constitucional tanto una primera residencia como una vivienda vacacional, o las habitaciones de hoteles, fondas o cualquier otro hospedaje.

En definitiva, cabe apreciar que tanto la aptitud de un espacio para desarrollar en él la vida privada como sus signos externos y el uso o destino dados a éste se van a erigir en los elementos esenciales, o verdaderos parámetros, para la delimitación de ese bien jurídico, objeto de tutela constitucional ${ }^{12}$.

En otro orden de cosas, hay que indicar que si ya de por sí el concepto de domicilio se delimita con notable amplitud, se observa en nuestro Ordenamiento un cierto efecto contagio, en virtud del cual se ha procedido a extender el régimen de garantías que se atribuye a los citados espacios, aplicándolo más allá de los razonables contornos que cabe atribuirle, en base al bien jurídico protegido.

Al respecto, los artículos 91.2 de la Ley Orgánica del Poder Judicial y 8.6 de la Ley de la Jurisdicción Contencioso-Administrativa aluden tanto a la entrada en domicilio como en los «restantes lugares cuyo acceso requiera el consentimiento de su titular», a la hora de exigir, en su caso, la autorización judicial correspondiente.

Esta determinación genérica encuentra concreción en el artículo 51 de la Ley de Expropiación Forzosa, en virtud del cual y en relación con la ocupación de los bienes inmuebles expropiados tienen la consideración de lugares cuyo acceso depende del consentimiento del titular, además del domicilio, en los términos del artículo 18. 2 de la Constitución española, «los locales cerrados sin acceso al público».

De esta forma, a efectos expropiatorios, se protegen de manera especial lugares antes no contemplados en la doctrina judicial, como son los almacenes, naves industriales o fábricas; quedando, en la práctica, únicamente excluidos de la pertinente autorización de entrada aquellos inmuebles, rústicos o urbanos, que aún permanezcan sin edificar ${ }^{13}$.

Tales espacios, como indica el Pleno del Tribunal Constitucional, en Sentencia de 17 de julio de 2014, van más allá del ámbito material

12 Vid. L. LAFont Nicuesa (2006), «La autorización judicial en el orden contenciosoadministrativo a las entradas y registros de la Hacienda Pública», Fórum Fiscal de Álava, mes 12, págs. 27-37; M. MARTínez García DE OtAzo (1998), «La autorización judicial para la entrada en el domicilio del deudor de los órganos de la recaudación de la Hacienda Pública: su evolución y requisitos, en La Constitución y la práctica del derecho, coords. Julián MarTíNEZ-Simancas SÁnCHEZ y Manuel ARAgón REYES, vol. 3, págs. 2705-2718.

13 Vid. J. E. BARRACHINA (2012), «Entrada de la inspección tributaria en domicilio de persona jurídica: el consentimiento preceptivo», Consell Obert: Recull Informatiu del Consell General de Col-legis de Graduats Socials de Catalunya, núm. 271, págs. 31-35; A. NAVARro FAURE (2011), «La entrada en el domicilio de las personas jurídicas y el principio de proporcionalidad», Crónica Tributaria, número extra 1, págs. 39-49. 
constitucionalmente protegido, obligando a los poderes públicos a obtener una autorización judicial protectora de un bien jurídico distinto, sin rango de derecho fundamental, como es la propiedad privada ${ }^{14}$ :

«El hecho de que el legislador haya otorgado especial protección a la entrada en los locales cerrados sin acceso al público, no necesariamente conlleva el reconocimiento de esa misma protección para los demás locales. Únicamente aquellos espacios que merecieran la consideración de domicilio, son los que se encuentran cubiertos por las garantías establecidas en el art. 18.2 CE (LA LEY 2500/1978), el cual establece que "ninguna entrada o registro podrá hacerse en él sin consentimiento del titular o resolución judicial, salvo en caso de flagrante delito"».

\section{EL TITULAR DEL DERECHO}

\section{La concreción del elemento subjetivo}

La jurisprudencia también ha impulsado la extensión de la garantía constitucional de la inviolabilidad del domicilio a través de una segunda vía, al atribuir la titularidad de este derecho no solo a las personas físicas, sino también a las jurídicas ${ }^{15}$.

Este hecho ha supuesto una nueva distorsión institucional, pues, según quedó señalado, respecto de las personas físicas, la garantía de la inviolabilidad del domicilio se vincula con la protección de la intimidad, referida a la vida personal y familiar; en cambio, tratándose de personas jurídicas, la protección del derecho se conecta con la intromisión en la actividad doméstica de la empresa y con la reserva que emana de la propiedad industrial, en los términos que viene a precisar la Sentencia de 26 de abril de 1999 del Tribunal Constitucional ${ }^{16}$ :

14 Vid. Sentencia 120/2014, de 17 de julio (Rec. 1756/2003). En la doctrina, vid. M. A. RuIZ LóPEZ (2011), «Autorización judicial de entrada en el domicilio y potestades administrativas: extensión del ámbito protegido, cuestiones procedimentales y proporcionalidad», Revista de Estudios de la Administración Local y Autonómica, núm. 317, págs. 215.

15 Vid. STC 120/2014, de 17 de julio, Rec. 1756/2003; STC 188/2013, de 4 de noviembre, Rec. 3769/2012; STC 150/2011, de 29 de septiembre, Rec. 5125/2003; STC 22/2003, de 10 de febrero, Rec. 4400/1999; STC 69/1999, de 26 de abril, Rec. 2824/1995; STC 137/1985.

16 Vid. Sentencia 69/1999, de 26 de abril, de la Sala Segunda del Tribunal Constitucional (Rec. 2824/1995). Igualmente, SSTC 283/2000, 69/1999, 171/1997. Precisamente, estos concretos contornos, bajo los que opera el concepto de domicilio en relación con las personas jurídicas, han venido provocando, en la práctica, ciertos problemas de inseguridad jurídica. Así 
«En lo que respecta a la titularidad del derecho que el art. 18.2 C.E. reconoce, necesariamente hemos de partir de la STC 137/1985 (...) Decisión en la que hemos declarado que la Constitución, "al establecer el derecho a la inviolabilidad del domicilio, no lo circunscribe a las personas físicas, siendo pues extensivo o predicable igualmente de las personas jurídicas" (en el mismo sentido, SSTC 144/1987 y 64/1988). Si bien esta afirmación de principio se ha hecho no sin matizaciones relevantes, entre ellas la consideración de la "naturaleza y especialidad de fines" de dichas personas (STC 137/1985, fundamento jurídico 5).

Tal afirmación no implica, pues, que el mencionado derecho fundamental tenga un contenido enteramente idéntico con el que se predica de las personas físicas. Basta reparar, en efecto, que, respecto a éstas, el domicilio constitucionalmente protegido, en cuanto morada o habitación de la persona, entraña una estrecha vinculación con su ámbito de intimidad, como hemos declarado desde la STC 22/1984, fundamento jurídico 5 (así como, SSTC 160/1991 y 50/1995, entre otras); pues lo que se protege no es solo un espacio físico sino también lo que en él hay de emanación de una persona física y de su esfera privada (STC 22/1984 y ATC 171/1989), lo que indudablemente no concurre en el caso de las personas jurídicas. Aunque no es menos cierto, sin embargo, que éstas también son titulares de ciertos espacios que, por la actividad que en ellos se lleva a cabo, requieren una protección frente a la intromisión ajena.

Por tanto, cabe entender que el núcleo esencial del domicilio constitucionalmente protegido es el domicilio en cuanto morada de las personas físicas y reducto último de su intimidad personal y familiar. Si bien existen otros ámbitos que gozan de una intensidad menor de

ocurre en los supuestos en los que la Administración Pública ejerce sus competencias de policía en distintos ámbitos, como es el caso de la contratación pública. El control llevado a cabo en las instalaciones que gestiona el concesionario de un servicio público puede dejar en manos de la Administración contratante la decisión de entrada en ciertos espacios en los que, a priori, se ignora su condición real de domicilio o sede social de la empresa. Una obligada cautela en el actuar de la Administración debe conducir a la solicitud de la autorización judicial, siempre que existan dudas sobre la verdadera condición jurídica que pueden ostentar determinados espacios en los que una entidad mercantil ejerce su actividad. 
protección, como ocurre en el caso de las personas jurídicas, precisamente por faltar esa estrecha vinculación con un ámbito de intimidad en su sentido originario; esto es, el referido a la vida personal y familiar, solo predicable de las personas físicas. De suerte que, en atención a la naturaleza y la especificidad de los fines de los entes aquí considerados, ha de entenderse que en este ámbito la protección constitucional del domicilio de las personas jurídicas y, en lo que aquí importa, de las sociedades mercantiles, solo se extiende a los espacios físicos que son indispensables para que puedan desarrollar su actividad sin intromisiones ajenas, por constituir el centro de dirección de la sociedad o de un establecimiento dependiente de la misma o servir a la custodia de los documentos u otros soportes de la vida diaria de la sociedad o de su establecimiento que quedan reservados al conocimiento de terceros».

Sin perjuicio de la extensión institucional producida en este punto, cabe advertir que tanto en el caso de una persona física como del de una persona jurídica, la titularidad del derecho a la inviolabilidad del domicilio resulta en gran medida ajena al título jurídico que pudiera ostentarse sobre el concreto lugar o espacio físico del que se predica tal condición.

Ciertamente, el titular del derecho que surge al amparo del artículo 18.2 de la Constitución española es la persona que vive en ese lugar, el morador, que bien puede ostentar la condición de propietario del bien o tratarse de un arrendatario, usufructuario o, incluso, de un simple precarista $^{17}$.

Por tanto, la titularidad del domicilio invoca una cierta tenencia sobre el concreto espacio en el que se desarrolla la vida íntima de la persona, pero en modo alguno debe confundirse la titularidad de ese último derecho con la del domicilio en cuanto bien jurídico protegido constitucionalmente.

Puede incluso sostenerse que si bien la opinión general de la doctrina pasa por exigir una cierta apariencia de legitimidad o de tolerancia su-

17 Vid. STSJ de la Comunidad Valenciana, Sala de lo Contencioso-Administrativo, Sección 1. , de 29 septiembre 2012, Rec. 1541/2011; STSJ de la Comunidad Valenciana, Sala de lo Contencioso-Administrativo, Sección 1. a , de 13 julio 2012, Rec. 1291/2011; STSJ de Andalucía de Granada, Sala de lo Contencioso-Administrativo, Sección 3. a , de 19 septiembre 2011, Rec. 556/ 2009; STSJ de Madrid, Sala de lo Contencioso-Administrativo, Sección 2. ${ }^{\text {a }}$, de 27 febrero 2009, Rec. 1726/2008; STSJ de Madrid, Sala de lo Contencioso-Administrativo, Sección 2. , de 25 noviembre 2008, Rec. 895/2008. 
ficiente por parte del dueño del bien, a la hora de poder disfrutar de la garantía de la inviolabilidad del domicilio, ese principio general quiebra en determinados supuestos.

Un ejemplo claro lo encontramos, nuevamente, en el caso del ejercicio de la potestad expropiatoria.

El titular del inmueble, una vez abonado o depositado el justiprecio y tras levantarse el acta de ocupación, ya no ostenta ningún derecho sobre el bien, real ni posesorio. Dicho inmueble ha pasado a manos de la Administración; sin embargo, ello no excluye que, ante una eventual oposición del sujeto expropiado, deba precisarse la necesidad de invocar la autorización judicial para la entrada en domicilio.

Por tanto, el derecho a la inviolabilidad del domicilio se presenta como una garantía jurídica que resiste ante la quiebra del título patrimonial sobre el bien físico o frente a la propia tolerancia del legítimo dueño de éste.

Del mismo modo, cabe afirmar que la protección que ofrece el artículo 18.2 de la Constitución española nace, de forma espontánea, ante situaciones que, a veces, resultan difícilmente apreciables ${ }^{18}$.

El caso más paradigmático puede ser la acampada de personas en la vía pública como acción reivindicativa o de protesta. En un primer momento cabría proceder a su desalojo, por razones de orden público, directamente a través de la intervención de las fuerzas de seguridad. Sin embargo, si esa acción de protesta se consolida en el tiempo por la tolerancia de la Administración, estaríamos hablando seguramente de un domicilio y, por lo tanto, de la necesidad de que los poderes públicos tengan que recabar la oportuna autorización judicial para entrar en dicho lugar.

2. La emisión del consentimiento y las excepciones a la necesidad de su prestación

La necesidad de obtener autorización judicial para la entrada en domicilio se enerva, como es lógico, cuando el titular del derecho ex-

18 Vid. J. E. BARRACHINA (2010), «Efectos jurídicos de la entrada en domicilio de la empresa, sin consentimiento del titular», Consell Obert: Recull Informatiu del Consell General de Col-legis de Graduats Socials de Catalunya, núm. 255, págs. 37-42; A. FríAs LóPEZ (2000), «Las autorizaciones judiciales de entrada en domicilio», Revista Jurídica de la Comunidad de Madrid, núm. 6, págs. 29-64; M. A. GARCíA VALDERREY (2009), «Las autorizaciones judiciales para la entrada del personal de la administración en domicilios particulares», Consultor de los Ayuntamientos y de los Juzgados: Revista técnica especializada en Administración Local y Justicia Municipal, núm. 4, págs. 597-611. 
presa su consentimiento. Ello exige, por tanto, conocer cómo ha de obtenerse dicha declaración de voluntad ${ }^{19}$.

Al respecto, lo que viene a desprenderse de la jurisprudencia constitucional es que no es necesario que el consentimiento sea expreso, ni que éste deba emitirse por escrito, aunque posteriormente se documente a efectos de su constancia. Su prestación, por tanto, podrá deducirse de ciertos hechos o de la conducta del titular del derecho, esto es, de la realización por el mismo de aquellos actos necesarios que de él dependan para dejar franca la entrada en el referido espacio, objeto de protección jurídica ${ }^{20}$.

En cualquier caso, el consentimiento ha de ser inequívoco, por lo que si existiese cualquier duda sobre la certeza de su prestación, ésta deberá disiparse de forma previa, con absoluta nitidez ${ }^{21}$.

El consentimiento, además, debe emitirse libremente, por lo que el titular del domicilio debe conocer la posibilidad de oponerse a la entrada y, como es obvio, no podrá ejercerse sobre él ningún tipo de presión, por liviana que ésta sea. Es decir, el consentimiento emitido no debe estar invalidado por error, violencia o intimidación de cualquier clase.

A su vez, el titular del domicilio debe estar en condiciones de poder manifestar su voluntad ${ }^{22}$. Por tanto, el consentimiento debe ser emiti-

19 Vid. R. García Macho (1982), «La inviolabilidad de domicilio», Revista Española de Derecho Administrativo, núm. 32, enero-marzo, págs. 85 y ss; J. M. RoJí BuQueRAs (2000), El derecho a la inviolabilidad del domicilio y la actuación de los órganos de la Inspección de los Tributos. Un estudio a propósito de la nueva Ley Jurisdiccional 29/1998, de 13 de julio, Impuestos, Ed. La Ley, pág. 14.

20 Vid. STC 22/1984, de 17 de febrero, Rec. 59/1983; STC 22/2003, de 10 de febrero, Rec. 4400/1999. Al respecto, en la doctrina, vid. V. MAGRo SERVET (2002), "Casuística sobre el concepto penal de domicilio en la diligencia de entrada y registro", La Ley: Revista jurídica española de doctrina, jurisprudencia y bibliografía, núm. 2, págs. 1764-1771; R. MARTíN Morales (1999), «Entrada en domicilio por causa de delito flagrante (a propósito de las SSTC 341/93 y 94/1996)», Revista Electrónica de Ciencia Penal y Criminología, núm. 1; T. MoLINA (2004), «La entrada y registro practicado por la policía en el supuesto de la flagrancia y la posesión de drogas en domicilio particular», Anuario Jurídico y Económico Escurialense, núm. 37, págs. 131-158.

21 Vid. STC 54/2015, de 16 de marzo, Rec. 2603/2013; STS de 22 octubre 2013, Rec. 147/ 2013; STS de 23 septiembre 2013, Rec. 2588/2012; STS de 9 octubre 2009, Rec. 311/2008; STS de 18 marzo 2003, Rec. 2146/2001; STSJ de Galicia, Sala de lo Contencioso-Administrativo, Sección 2. ${ }^{\text {, }, ~ 201 / 2015, ~ d e ~} 26$ de marzo, Rec. 4060/2015; STSJ del Principado de Asturias, Sala de lo Contencioso-Administrativo, Sección 1. a, 180/2015, de 16 de marzo, Rec. 16/2015; STSJ de Cataluña, Sala de lo Contencioso-Administrativo, Sección 1. a, 293/2015, de 12 de marzo, Rec. 153/2014; STSJ de Galicia, Sala de lo Contencioso-Administrativo, Sección 2. ', 158/2015, de 12 de marzo, Rec. 4496/2014; STSJ de Madrid, Sala de lo Contencioso-Administrativo, Sec-

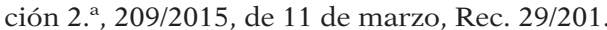

22 Ello, evidentemente, no ocurre cuando el titular del derecho se encuentre con síntomas evidentes de embriaguez o de haber ingerido sustancias psicotrópicas, que alteren de manera sensible su consciencia. Vid. Y. DE LUCCHI LÓPEZ-TAPIA (2000), «Entrada y registro en domi-

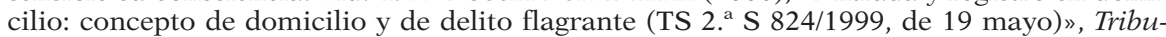


do por quien no presente una restricción en su capacidad de obrar y, en todo caso, por un mayor de edad.

Otra cuestión que cabe plantearse es la disponibilidad misma sobre el consentimiento prestado. Aparentemente, el titular del derecho puede revocar libremente su declaración de voluntad; ahora bien, esa posibilidad no está exenta de polémica ya que bajo el ejercicio de esa facultad se podría poner fin a una actuación de inspección en marcha, obstaculizando gravemente las labores de investigación y sus eventuales resultados.

Por otro lado, el consentimiento debe prestarlo personalmente el titular del derecho, aunque hay ejemplos, también, de consentimientos emitidos por los familiares de una persona enferma. En estos supuestos, parece necesario acreditar la representación por medio de la cual se actúa, de acuerdo a lo dispuesto en el artículo 32 de la Ley 30/1992, de Régimen Jurídico y Procedimiento Administrativo Común, para los supuestos de renuncia a un derecho.

La duda se plantea, sin embargo, en los supuestos de titularidades compartidas $^{23}$; si bien, en estos casos, cuando todos los ocupantes ostentan idéntico derecho, parece procedente que debe primar la prohibición de entrada que oponga una de esas personas, frente al consentimiento que pudiera otorgar el resto ${ }^{24}$.

Cuestión distinta es cuando una persona autoriza la convivencia de otras en su domicilio. En tal caso, cabría entender que estas últimas tienen un ejercicio condicionado del derecho en relación con el primero.

Finalmente, hay que señalar que la necesidad de obtener el consentimiento del titular del derecho queda excepcionada en dos supuestos concretos, que gozan de desigual cobertura jurídica.

nales de Justicia: Revista Española de Derecho Procesal, núm. 3, págs. 387-390; J. J. HERNÁNDEZ Domínguez (2012), "Supuestos constitucionales que posibilitan la entrada y registro en domicilio", Revista de Derecho Penal, núm. 36, págs. 97-115; J. LóPEz BARJA DE Quiroga (1993), "La entrada y registro en domicilio», en Politica criminal y reforma penal: homenaje a la memoria del Prof. Dr. D. Juan del Rosal, págs. 761-791.

23 Sería el caso de la vivienda de una persona que es a la vez domicilio social de una sociedad, o del domicilio de cónyuges separados judicialmente que por necesidades económicas siguen compartiendo vivienda; o, también, el de unos estudiantes que comparten piso.

24 Vid. J. J. Hernández Domínguez (2012), «Supuestos constitucionales que posibilitan la entrada y registro en domicilio», Revista de Derecho Penal, núm. 36, págs. 97-115; J. LóPEZ BARJA DE Quiroga (1993), «La entrada y registro en domicilio», en Política criminal y reforma penal: homenaje a la memoria del Prof. Dr. D. Juan del Rosal, págs. 761-791; V. MAgro SERVET (2002), "Casuística sobre el concepto penal de domicilio en la diligencia de entrada y registro», La Ley: Revista jurídica española de doctrina, jurisprudencia y bibliografía, núm. 2, págs. 1764-1771; R. MARTín Morales (1999), «Entrada en domicilio por causa de delito flagrante (a propósito de las SSTC 341/93 y 94/1996)», Revista Electrónica de Ciencia Penal y Criminología, núm. 1. 
Al primero de ellos alude el propio artículo 18.2 de la Constitución española, que, como es sabido, permite llevar a cabo la entrada en un domicilio o su registro en caso de flagrante delito.

En estos supuestos, no obstante, la jurisprudencia viene imponiendo la concurrencia de un doble requisito ${ }^{25}$. Por un lado, se exige que el delincuente sea sorprendido en el momento de consumar los hechos o en circunstancias inmediatas a la perpetración. Por otro lado, se requiere que la entrada en el domicilio sea urgente; extremo éste que supone que se pueda impedir la consumación del delito, o bien que se pueda detener al responsable o se evite la desaparición de efectos ${ }^{26}$.

El segundo de los supuestos que eximen de la necesidad de contar con el consentimiento del titular del derecho es el caso de estado de necesidad $^{27}$.

Así, la Ley Orgánica 4/2015, de 30 de marzo, de protección de la seguridad ciudadana, proclama en su artículo 15 que es causa legítima suficiente para la entrada en domicilio la necesidad de evitar daños inminentes y graves a las personas y a las cosas, en supuestos de catástrofe, calamidad, ruina inminente u otros semejantes de extrema y urgente necesidad.

Sin embargo, la cobertura constitucional para quebrar en estos casos la inviolabilidad del domicilio no cabe encontrarla en el citado artículo 18.2 de la Constitución española. No obstante, otros derechos fundamentales consagrados en la propia Carta Magna, como son el derecho a la vida y a la integridad física (art. 15) o el derecho a la seguridad de las personas (art. 17.1), avalan dicha intervención ${ }^{28}$.

25 Vid. STC 22/2003, de 10 de febrero, Rec. 4400/1999; STC 94/1996, de 28 de mayo, Rec. 202/1995. En la doctrina, vid. J. LÓPEz BARJA DE QUIROGA (1993), «La entrada y registro en domicilio", en Política criminal y reforma penal: homenaje a la memoria del Prof. Dr. D. Juan del Rosal, ISBN 84-7130-785-5, págs. 761-791; R. MARTín Morales (1999), «Entrada en domicilio por causa de delito flagrante (a propósito de las SSTC 341/93 y 94/1996)», Revista Electrónica de Ciencia Penal y Criminología, núm. 1

26 Vid. T. Molina (2004), "La entrada y registro practicado por la policía en el supuesto de la flagrancia y la posesión de drogas en domicilio particular», Anuario Jurídico y Económico Escurialense, núm. 37, págs. 131-158; E. Morales MuÑoz (2007), «Diligencias de investigación: Registro domiciliario: cuestiones generales y consentimiento titular. Situaciones de flagrancia (I)», Boletín del Ministerio de Justicia, año 61, núm. 2036, págs. 1841-1858.

27 Vid. M. A. RuIz LóPez (2011), «Autorización judicial de entrada en el domicilio y potestades administrativas: extensión del ámbito protegido, cuestiones procedimentales y proporcionalidad», Revista de Estudios de la Administración Local y Autonómica, núm. 317, pág. 228.

28 Vid. STC 22/1984, de 17 de febrero, Rec. 59/1983. Al respecto, vid. en la doctrina J. M. Macías CASTAÑo (2001), «El desahucio administrativo. La problemática de su ejecución: la entrada en un domicilio y la jurisprudencia constitucional», Seminari.fmc.cat., pág. 20; P. J. Maldonado Canito (2012), "Procedimiento de solicitud de entrada en domicilio en fase administrativa y jurisdiccional», Iuris: Actualidad y Práctica del Derecho, núm. 171, págs. 52-59. 
Si alguna objeción cabe encontrar en nuestro Ordenamiento al respecto es que la mencionada Ley Orgánica, en virtud de su objeto, limita la facultad de entrada en domicilio, en los casos de estado de necesidad, en general, a las Fuerzas y Cuerpos de Seguridad.

Esta circunstancia y la falta de una previsión análoga en otras normas sectoriales dejan sin cobertura directa en la legislación aplicable la acción de otros cuerpos de intervención en este tipo de situaciones de extrema y urgente necesidad, como es el caso de los servicios de extinción de incendios o los equipos de protección civil.

\section{LA RESTRICCIÓN DE LA AUTOTUTELA EJECUTIVA DE LA ADMINISTRACIÓN}

\section{La intervención judicial como acto de apoderamiento de la Admi-} nistración

Fuera de los casos ya indicados, de obtención del consentimiento del titular, delito flagrante o estado de necesidad, la entrada en domicilio exige contar con la pertinente resolución judicial.

Según queda dicho, la Constitución española sitúa al juez ordinario como primer garante de la inviolabilidad del domicilio, obligando a las Administraciones Públicas a recabar la mencionada autorización para el desenvolvimiento de su actividad en defensa de los intereses generales ${ }^{29}$.

La necesidad de intervenir en el domicilio de un particular responde, en general, a dos tipos de manifestaciones del actuar de la Administración: los casos de ejecución forzosa de actos administrativos; y los supuestos de inspección o comprobación ${ }^{30}$.

En esa primera categoría, cuyo análisis constituye el eje principal del presente estudio, cabría encuadrar actuaciones tales como los de-

29 Vid. V. FAIRÉN GuILLÉN (1993), «Algunas ideas básicas sobre la "entrada y registro en domicilio" (del artículo 21 de la ley 1/1992, de protección de la seguridad ciudadana, de 21 de febrero)», Revista de Derecho Procesal, núm. 1, págs. 11-60; J. FERnÁndez-Corredor SÁNCHEZ-DiezMa (2009), «Entrada a domicilio. Medida administrativa», CEFLegal: Revista Práctica de Derecho. Comentarios y casos prácticos, núm. 103, pág. 175; M. A. GARcía VALDERREY (2009), "Las autorizaciones judiciales para la entrada del personal de la administración en domicilios particulares», Consultor de los Ayuntamientos y de los Juzgados: Revista técnica especializada en Administración Local y Justicia Municipal, núm. 4, págs. 597-611.

30 Las labores de inspección y comprobación que realizan las Administraciones Públicas, y que requieren la entrada en domicilio, abarcan, entre otras, la actividad de lucha contra el fraude que despliega la Agencia Tributaria; las actuaciones de control llevadas a cabo en materia de sanidad y consumo, en el ámbito del mercado laboral y la Seguridad Social; o la propia actividad de policía que, en el marco de la ejecución de contratos, se realiza sobre los concesionarios de los servicios públicos. 
sahucios administrativos de concesionarios del dominio público ${ }^{31}$, la ocupación o toma de posesión de bienes en los procedimientos de expropiación forzosa y, en el ámbito del Urbanismo, el cumplimiento forzoso de órdenes de ejecución o la adopción de medidas para el restablecimiento de la legalidad ${ }^{32}$.

En todas esas manifestaciones que han de implicar la entrada en domicilio, la intervención judicial se traduce en un acto de autorización que levanta un obstáculo para el ejercicio de una potestad administrativa, insertándose en el procedimiento como un trámite más a modo de refuerzo de la protección de los derechos y libertades públicos ${ }^{33}$.

En definitiva, con la autorización judicial de la entrada en domicilio se viene a apoderar a la Administración Pública para realizar una determinada actuación en garantía de un bien jurídico prevalente; extremo éste que adquiere una particular relevancia a la hora de entender cuál es la verdadera naturaleza de la acción que los tribunales despliegan al amparo del artículo 18.2 de la Constitución española.

En este sentido, y tal como tiene indicado el Tribunal Superior de Justicia de Castilla y León, en Sentencia de 13 de junio de $2014^{34}$, cabe concluir que:

«La autorización es por tanto la forma de proteger la inviolabilidad del domicilio frente a actuaciones arbitrarias de la Administración, pero no puede convertirse en un obstáculo que impida a la misma el necesario ejercicio de sus facultades o competencias de policía administrativa; debiendo el juez de valorar si la actuación está justificada en el ámbito de las competencias y deberes de la propia Administración».

31 Vid. L. Chacón ORTEga (1992), «Recuperación de oficio de los bienes de las entidades locales y la entrada en el domicilio a la luz de la sentencia del Tribunal Constitucional 160/1991, de 18 de julio», Revista de Estudios de la Administración Local y Autonómica, núm. 253, págs. 105-118.

32 Vid. VV.AA. (2010), «Urbanismo. Ruina._La entrada en un domicilio, cuando no medie consentimiento de su titular, debe estar autorizada judicialmente», Consultor de los Ayuntamientos y de los Juzgados: Revista técnica especializada en Administración Local y Justicia Municipal, núm. 9, págs. 1409-1410; VV.AA. (2013), «Urbanismo. Disciplina urbanística.—Entrada en domicilio para inspección por infracción urbanística», Consultor de los Ayuntamientos y de los Juzgados: Revista técnica especializada en Administración Local y Justicia Municipal, núm. 7, págs. 683-684.

33 Vid. M. LAFUENTE BENACHEs (1992), La ejecución forzosa de los actos administrativos por la Administración Pública, Tecnos, Madrid, pág. 85.

34 Vid. Sentencia 147/2014, de 13 de junio (Rec. 56/2014). 


\section{La situación jurídica del acto a ejecutar}

Un extremo esencial que la Administración Pública y el propio órgano judicial han de tener presente a la hora de formular y resolver, respectivamente, la solicitud de entrada en domicilio es la situación del acto administrativo cuya ejecución forzosa se pretende llevar a cabo ${ }^{35}$.

De esa situación va a depender directamente la posibilidad de obtener, o no, la mencionada autorización, pudiendo encontrarnos en este punto ante muy variados supuestos ${ }^{36}$.

En primer lugar, cabe que el acto administrativo cuya ejecución se pretende llevar a cabo no haya sido, siquiera, objeto de impugnación, en cuyo caso podrá obtenerse la autorización judicial de entrada en domicilio, incluso, aunque dicho acto todavía no hubiese adquirido firmeza ${ }^{37}$.

La segunda posibilidad es que el acto administrativo haya sido objeto de impugnación, pero que no esté suspendido, lo cual, a su vez, puede obedecer a diferentes motivos y generar situaciones diversas.

De este modo cabe, por ejemplo, que, no habiéndose solicitado la suspensión con carácter previo, se formule ésta una vez que la Administración obtiene la autorización judicial de entrada en domicilio.

A este respecto, procede señalar que siempre que un acto administrativo es recurrido y se encuentra pendiente de resolución sobre la suspensión de su eficacia, la Administración no puede proceder a su ejecución forzosa ya que impediría la obtención de la tutela judicial efectiva. En estos casos, solo el órgano jurisdiccional que deba conocer de la suspensión será también el competente para resolver sobre la autorización de entrada, impidiéndose así la interferencia que el llamado

35 La entrada en domicilio se manifiesta con una peculiaridad diferente en los casos de ejecución forzosa de actos administrativos, frente a los supuestos de comprobación o inspección. En concreto, en este último tipo de intervenciones de la Administración Pública no existe un procedimiento previo finalizado por un acto, sino que se trata de actuaciones realizadas dentro de un procedimiento en curso. Al no existir un acto administrativo previo, el particular no tiene la oportunidad de impugnarlo y de solicitar la suspensión. Tampoco va a tener, por tanto, la oportunidad de cumplir voluntariamente con su contenido, enervando así la entrada en su domicilio. En definitiva, la posición del ciudadano es mucho más débil y los parámetros del control judicial para autorizar la entrada difieren en gran medida.

36 Vid. J. M. Rojí BuQueras (2000), El derecho a la inviolabilidad del domicilio y la actuación de los órganos de la Inspección de los Tributos. Un estudio a propósito de la nueva Ley Jurisdiccional 29/1998, de 13 de julio, Impuestos, Ed. La Ley, pág. 22 y ss.

37 Ello no es más que la consecuencia del principio de inmediata ejecutividad de los actos administrativos (arts. 94 y 111 de la Ley de Régimen Jurídico y Procedimiento Administrativo Común), y así lo han confirmado, entre otras, las SSTC 199/1988, 144/1987 y 22/1984. 
«juez de garantías» podría llegar a producir en la acción del órgano jurisdiccional que tramita el proceso principal ${ }^{38}$.

En efecto, tal como señala la Sentencia del TSJ de Madrid de 10 de enero de $2013^{39}$ :

«El conocimiento del recurso contencioso-administrativo contra una actuación administrativa confiere al órgano jurisdiccional competente la más amplia cognición, no sólo sobre su conformidad a derecho, sino, además, acerca de su ejecutividad, de forma y manera que, como expresa la STC 199/98, "hasta que no se tome la decisión al respecto por el Tribunal competente, el acto no puede ser ejecutado por la Administración, porque en tal hipótesis ésta se habría convertido en Juez (STC 78/1996), pero tampoco cabe la ejecución por otro órgano judicial distinto porque esta eventualidad impediría que aquel Tribunal, el competente, pudiera conceder eficazmente la tutela tal y como le impone el derecho fundamental (STC 76/1992)"».

En el mismo sentido se manifiesta la Sentencia del TSJ de Castilla y León de 28 de octubre de $2011^{40}$ :

«El derecho a la tutela judicial efectiva garantizado en el art. 24.1 CE implica que los ciudadanos puedan acudir a los Tribunales para impugnar los actos de la Administración (arts. 106.1 y 117.3 CE) y obtener un pronunciamiento sobre la ejecutividad o la suspensión de los mismos (por todas, STC 76/1992, F. 3). En segundo lugar, también por imperativo del art. 24.1 CE, cuando el órgano judicial competente se pronuncie sobre la ejecutividad o suspensión a él sometida, su decisión puede llevarla a cabo, lo que impide que otros órganos del Estado, sean administrativos o sean de otro orden jurisdiccional distinto, resuelvan sobre tal pretensión, interfiriéndose de esa manera en el proceso judicial de que

38 Vid. J. M. Macías CAStaño (2001), «El desahucio administrativo. La problemática de su ejecución: la entrada en un domicilio y la jurisprudencia constitucional», Seminari.fmc.cat., pág. 21-22.

39 Vid. Sentencia 17/2013, Rec. 1353/2012.

40 Vid. Sentencia 2481/2011, Rec. 545/2011. 
conoce el Tribunal competente y convirtiendo así en ilusoria e ineficaz la tutela que pudiera dispensar éste. Hasta que no se tome la decisión al respecto por el Tribunal competente, el acto no puede ser ejecutado por la Administración, porque en tal hipótesis ésta se habría convertido en Juez, pero tampoco cabe la ejecución por otro órgano judicial distinto porque esta eventualidad impediría que aquel Tribunal, el competente, pudiera conceder eficazmente la tutela».

Cabe, también, plantearse si, una vez interpuesto el recurso contra el acto, aunque no se haya solicitado la suspensión de éste, resulta pertinente el otorgamiento de la autorización de entrada en domicilio, en tanto que la medida cautelar podría llegar a pedirse en cualquier momento del proceso ${ }^{41}$.

En este punto la doctrina judicial mayoritaria se inclina por entender que hasta que no se haya solicitado la suspensión del acto administrativo es posible conceder dicha autorización ${ }^{42}$. Así se desprende, entre otras, de la Sentencia del TSJ de Andalucía de 29 de mayo de 200943 .

«No consta que frente a tal actuación expropiatoria se haya interpuesto recurso jurisdiccional ni que, en el caso de que así fuera, el Órgano jurisdiccional haya acordado la medida cautelar de suspensión de la actuación expropiatoria».

De manera coincidente, la Sentencia del TSJ de Cantabria de 3 de julio de $2014^{44}$ señala:

41 Vid. A. Navarro Faure (2011), «La entrada en el domicilio de las personas jurídicas y el principio de proporcionalidad», Crónica Tributaria, número extra 1, págs. 39-49; J. L. RASCÓN ORTEGA (2000), «La entrada y registro como límite al derecho a la inviolabilidad del domicilio", Estudios Jurídicos. Cuerpo de Secretarios Judiciales, núm. 1 (ejemplar dedicado a «Actuaciones del Juzgado de Guardia en relación con los Derechos Fundamentales. Catástrofes y emergencias: respuesta de la Administración de Justicia. Protección de datos jurídicos»), págs. 241-278; J. Vegas ToRREs (1993), «Autorización judicial para entrada en domicilio en procedimiento de recaudación de la Seguridad Social; límites de la Ley de Presupuestos: inconstitucionalidad del artículo 130 de la Ley General Tributaria», Civitas. Revista Española de Derecho del Trabajo, núm. 61, págs. 789-800.

42 Vid. M. A. García VAlderrey (2009), "Las autorizaciones judiciales para la entrada del personal de la administración en domicilios particulares», Consultor de los Ayuntamientos y de los Juzgados: Revista técnica especializada en Administración Local y Justicia Municipal, núm. 4, págs. 597-611; P. MoRell GALINDo (2003), «La autorización judicial de entrada en el domicilio», Cuadernos de Derecho Local, núm. 2, págs. 100-110.

43 Vid. Sentencia 334/2009, Rec. 1717/2008.

44 Vid. Sentencia 281/2014, Rec. 68/2014. 
«Esta ejecutividad de los actos administrativos cesa cuando se adopte una medida cautelar de las previstas en el artículo 129 y siguientes de la LJCA, supuesto que no concurre en el presente caso, al no haberse acreditado que se siga un proceso contencioso contra el acto administrativo que se pretende ejecutar y que dentro de ese proceso, se haya solicitado la suspensión del acto impugnado».

En cualquier caso, también cabe advertir que algunos pronunciamientos se han venido decantando por una postura mucho más restrictiva al respecto. De esta opinión es la Sala del TSJ de Madrid, que, en su Sentencia de 20 de febrero de $2013^{45}$, concluyó del siguiente modo:

«Si la Administración no puede ejecutar sus actos cuando su ejecutividad se halla sometida al conocimiento de la jurisdicción contencioso-administrativa, ni puede autorizarlo otro órgano jurisdiccional que no sea el que conoce del asunto principal, es claro que sólo cabe atribuir la competencia para autorizar la entrada en el domicilio necesaria para la ejecución del acto al órgano jurisdiccional que conoce sobre el asunto principal incluso en el supuesto de que no se hubiera solicitado aún la medida cautelar de suspensión toda vez que, conforme a lo dispuesto por el art. 129.1 LJCA, los interesados la pueden solicitar en cualquier estado del proceso».

Igualmente, se ha defendido, en ocasiones, que si se solicita la suspensión del acto administrativo y no se concede la misma, el auto de denegación podría resultar suficiente para entender autorizada la entrada en el domicilio.

Tal planteamiento, sin embargo, entendemos que debe ser rechazado, pues, como luego veremos, el auto que se pronuncia sobre la medida cautelar no contiene todos los requisitos que se exigen a la resolución de autorización de entrada, de ahí que aquélla no puede servir para evitar la obtención de un nuevo pronunciamiento judicial, directamente orientado al mencionado fin.

En último término, debemos aludir a aquellos actos administrativos que han sido declarados legales mediante sentencia firme y que aún están pendientes de ser ejecutados por la propia Administración.

45 Vid. Sentencia 210/2013, Rec. 922/2011. 
La jurisprudencia inicial del Tribunal Constitucional entendió que, también en este caso, resultaba necesaria una segunda resolución judicial, mediante la cual se apoderase formalmente a la Administración actuante en el ejercicio de la autotutela ejecutiva ${ }^{46}$.

Esta postura, que fue duramente criticada por la doctrina administrativista ${ }^{47}$, se replanteó tras la STC de 18 de julio de 1991, entendiéndose que, en estos supuestos, de lo que se trata, en realidad, es de la ejecución de sentencias, no de actos administrativos ${ }^{48}$ :

«Debemos apartarnos, en los términos previstos en el art. 13 LOTC, de la doctrina sentada en la Sentencia 22/1984, en lo que constituía su ratio decidendi, acerca de la exigencia de una duplicidad de resoluciones judiciales. Corresponde al Juez, según lo señalado, y de acuerdo con el art. 18.2 C.E., llevar a cabo la ponderación preventiva de los intereses en juego como garantía del derecho a la inviolabilidad del domicilio. Y una vez realizada tal ponderación, se ha cumplido el mandato constitucional. La introducción de una segunda resolución por un Juez distinto no tiene sentido en nuestro ordenamiento, una vez producida, en el caso que se trata, una Sentencia firme en la que se declara la conformidad a Derecho de una resolución expropiatoria que lleva anejo el correspondiente desalojo. Pues no cabe, una vez firme la resolución judicial, que otro órgano jurisdiccional entre de nuevo a revisar lo acordado y a reexaminar la ponderación judicial efectuada por otras instancias, que pudieran ser incluso de órdenes jurisdiccionales distintos, o de superior rango en la jerarquía jurisdiccional, pues ello iría en contra de los más elementales principios de seguridad jurídica. Y si no es posible una intervención judicial revisora, tampoco resulta admisible una segunda resolución judicial que no efectuara esa revisión, pues se convertiría en una actuación meramente automática o mecánica, confirmadora de la decisión judicial a ejecutar, lo que no constituye garantía jurisdiccional alguna ni responde a lo dispuesto en el art. 18.2 C.E.».

\footnotetext{
46 Vid. STC 22/1984.

47 Vid. A. NiETo GARCÍA (1987), «Actos administrativos cuya ejecución precisa una entrada domiciliaria», $R A P$, núm. 112, pág. 56.

48 Vid. Sentencia 160/1991, de 18 de julio, RTC $1991 \backslash 160$.
} 
Se consagró así, de este modo, el criterio en virtud del cual, una vez firme una resolución jurisdiccional, no procede que otro tribunal de justicia entre de nuevo a revisar lo acordado; lo que, en la práctica, supuso excluir del ámbito del artículo 87.2 de la Ley Orgánica del Poder Judicial toda entrada en domicilio que sea consecuencia de la ejecución de sentencias o resoluciones emitidas por los órganos jurisdiccionales.

De esa doctrina judicial también resulta expresiva, entre otras muchas, la Sentencia de 28 de febrero de 2007 del TSJ de Extremadura ${ }^{49}$ :

«La Sentencia de esta Sala de 27 de septiembre de 2001, desestimaba el recurso contencioso-administrativo interpuesto contra la resolución del Ayuntamiento de Serrejón (Cáceres) de 20-1-98, en que se acordaba no legalizar obras en suelo no urbanizable, denegando la licencia solicitada, y ordenando la demolición de las mismas, acto administrativo que ya contenía, de forma directa, la autorización que se pretende, como hemos expuesto, ya que existe una identidad absoluta entre el acto de ejecución material y su título habilitante, de ahí que el Ayuntamiento no precise de nueva autorización judicial de entrada para ejecutar tales actos contenidos en sentencia judicial firme, pudiendo y debiendo ejecutar los mismos sin solicitar autorización judicial que la tiene concedida en la sentencia firme de referencia, y sin perjuicio de que en un incidente de ejecución de sentencia, se resuelva cualquier cuestión que se plantee en ejecución de tal sentencia firme, que se enmarca en el ámbito del derecho a la tutela judicial efectiva».

Esta jurisprudencia, sin embargo, no está exenta de problemas a la hora de prestar una garantía eficaz al bien jurídico objeto de protección.

En teoría, firme la sentencia, no habría que preavisar para proceder a la entrada en el domicilio, ni siquiera que dar oportunidad al titular del derecho para que éste pueda dar cumplimiento voluntario al contenido del acto administrativo.

Además, tampoco parece exigirse que la sentencia que resuelve sobre la legalidad del acto deba, asimismo, establecer el modo en que ha de producirse la entrada en el domicilio, con el fin de causar la menor distorsión posible.

49 Vid. Sentencia 58/2007, Rec. 203/2006. 
Por otro lado, hay que tener presente que, frente a determinados supuestos (como podría ser una expropiación o una demolición), cuya ejecución puede determinar necesariamente la entrada en domicilio, tal exigencia no siempre se da en otras ocasiones de forma tan directa ${ }^{50}$.

A este respecto, debe precisarse que para que la confirmación por el órgano judicial del acto que implica la entrada en domicilio excluya la necesidad de obtener una autorización posterior para llevar a cabo la misma, es preciso que la entrada suponga una «ejecución en línea directa o de continuidad» con el acto confirmado al llevar implícita la entrada en domicilio ${ }^{51}$.

En caso contrario, la autorización seguirá siendo necesaria, aunque el juez que deba pronunciarse al respecto no realizará una nueva revisión de la validez del acto a ejecutar, sino de los extremos relacionados con la específica función de garantía que tiene atribuida constitucionalmente ${ }^{52}$.

\section{El CONTROL JUDICIAL DE LA ENTRADA EN DOMICILIOS}

\section{El procedimiento para la obtención de la autorización judicial}

Al margen de la cobertura que ofrece el texto constitucional, la única concreción normativa sobre el procedimiento de autorización de entrada en domicilio es que el mismo concluye mediante auto y que frente a esta resolución cabe interponer recurso de apelación ${ }^{53}$.

50 Así, por ejemplo, en una sentencia que se pronuncie sobre la legalidad de una sanción administrativa, la ejecución del contenido del acto no implica de forma necesaria la entrada en domicilio. Si luego hay incumplimiento y hubiese que embargar bienes se requeriría ulteriormente dicha entrada, pero en ese supuesto sí sería necesario solicitar autorización judicial, sin poder encontrar amparo directo en la sentencia inicial que se pronunció sobre la legalidad de dicha sanción. Vid. M. LAFUEnTE BEnACHEs (1992), «Reflexiones sobre la inviolabilidad del domicilio (a propósito de la STC 160/1991, de 18 de julio)», Revista Española de Derecho Administrativo, núm. 73, enero-marzo, pág. 79 y ss.

51 Vid. L. LAFONT Nicuesa (2006), «La autorización judicial en el orden contencioso-administrativo a las entradas y registros de la Hacienda Pública», Fórum Fiscal de Álava, mes 12, págs. 27-37; M. MARTínez GARcía DE OTAZo (1998), «La autorización judicial para la entrada en el domicilio del deudor de los órganos de la recaudación de la Hacienda Pública: su evolución y requisitos», en La Constitución y la práctica del derecho, coords. Julián MaRTínezSimancas SÁnchez y Manuel Aragón ReYes, vol. 3, págs. 2705-2718.

52 Vid. M. LAFUENTE BenACHES (1992): «Reflexiones sobre la inviolabilidad del domicilio (a propósito de la STC 160/1991, de 18 de julio)», Revista Española de Derecho Administrativo, núm. 73, enero-marzo, págs. 79 y ss; J. M. MAcías CASTAÑo (2001), «El desahucio administrativo. La problemática de su ejecución: la entrada en un domicilio y la jurisprudencia constitucional», Seminari.fmc.cat., págs. 21-22.

53 Vid. artículos 91.2 de la LOPJ y 80 de la LJCA. 
Por esa razón, el régimen jurídico a examinar debe inferirse de la jurisprudencia y de la praxis judicial, desde donde habrá que encontrar respuesta a las numerosas lagunas que existen en relación con esta figura $^{54}$.

La primera incógnita que nos encontramos es si el intento previo de obtención de consentimiento es un requisito para poder abrir el camino a la vía judicial. Esto es, si la autorización de entrada es subsidiaria respecto del consentimiento del interesado o puede producirse sin necesidad alguna de que se requiera dicha anuencia ${ }^{55}$.

En los casos en los que la entrada en domicilio se encuentra de algún modo vinculada a una actuación administrativa de investigación y comprobación, el hecho mismo de recabar el consentimiento previo del afectado podría frustrar la finalidad del acceso ${ }^{56}$. Entendemos que solo en estos supuestos adquiere sentido la jurisprudencia emitida por el Tribunal Constitucional, que viene sosteniendo que la autorización judicial de entrada en domicilio no en todo caso debe ser posterior al requerimiento de consentimiento ${ }^{57}$.

En cuanto a la competencia judicial para emitir dicha autorización, hay que indicar que el conocimiento sobre este tipo de procedimientos se atribuyó inicialmente a los Juzgados de Instrucción ${ }^{58}$, si bien trece años después esa competencia quedó residenciada en los Juzgados de lo Contencioso-Administrativo ${ }^{59}$.

54 Vid. STC 188/2013, de 4 de noviembre, Rec. 3769/2012; STC 150/2011, de 29 de septiembre, Rec. 5125/2003; STC 22/2003, de 10 de febrero, Rec. 4400/1999. En la doctrina, vid. C. Álvarez-Linera URÍA (1989), «La autorización judicial para la entrada en domicilios particulares, en ejecución de actos administrativos», La Ley: Revista jurídica española de doctrina, jurisprudencia y bibliografía, núm. 1, págs. 1037-1045; V. ManTECa Valdelande (2011), «La compulsión sobre las personas como instrumento ejecutivo de la Administración Pública (y 2)», Actualidad Administrativa, núm. 17, pág. 6.

55 Vid. M. A. García VAlderrey (2009), "Las autorizaciones judiciales para la entrada del personal de la administración en domicilios particulares», Consultor de los Ayuntamientos y de los Juzgados: Revista técnica especializada en Administración Local y Justicia Municipal, núm. 4, págs. 597-611; L. LAFONT NiCUESA (2006), «La autorización judicial en el orden contencioso-administrativo a las entradas y registros de la Hacienda Pública», Fórum Fiscal de Álava, mes 12, págs. 27-37; V. MANTECA VALDELANDE (2011), «La compulsión sobre las personas como instrumento ejecutivo de la Administración Pública (y 2)», Actualidad Administrativa, núm. 17, pág. 6; A. NAVARro FAure (2011), «La entrada en el domicilio de las personas jurídicas y el principio de proporcionalidad», Crónica Tributaria, número extra 1, págs. 39-49; J. OLIVÁN DEL CACHO (2011), «La autorización judicial para la entrada en domicilio y restantes lugares cuyo acceso requiera el consentimiento de su titular: aspectos prácticos», Asamblea: Revista Parlamentaria de la Asamblea de Madrid, núm. 25, págs. 197-212.

56 Vid. J. M. Rojí BuQueras (2000), El derecho a la inviolabilidad del domicilio y la actuación de los órganos de la Inspección de los Tributos. Un estudio a propósito de la nueva Ley Jurisdiccional 29/1998, de 13 de julio, Impuestos, Ed. La Ley, pág. 29.

57 Vid. STC 120/2014, de 17 de julio, Rec. 1756/2003.

58 Vid. artículo 87.2 de la LOPJ.

59 Esta previsión, no obstante, ha estado sujeta a excepciones, pues en caso de plantearse la solicitud de entrada en domicilio en días u horas no hábiles, la competencia llegó a co- 
En concreto, será, normalmente, el Juzgado que por turno corresponda, del lugar en el que radique el domicilio, el encargado de emitir dicha autorización. No obstante, en los casos en los que se haya incoado previamente recurso contencioso-administrativo contra el acto que se pretende ejecutar, la competencia para conocer del asunto ha sido desplazada, en la práctica, hacia el órgano judicial en el que se ha venido sustanciando este último procedimiento. Así lo tiene señalado, entre otras, la Sentencia del TSJ de Madrid de 20 de febrero de $2013^{60}$ :

«Esta Sala y Sección, en sintonía con la doctrina expuesta en las Sentencias de la Sala de lo ContenciosoAdministrativo del País Vasco de 14 de octubre de 2005 (recurso de apelación núm. 393/2005 ) y 22 de junio de 2004 (recurso de apelación núm. 145/2000 ), se inclina por el criterio de que la competencia del órgano que conoce del recurso contencioso-administrativo contra el acto que se trata de ejecutar en orden a la autorización de entrada en el domicilio del interesado que se alza contra el acto administrativo se extiende a la autorización de entrada para su ejecución».

En cuanto a la tramitación a seguir por el órgano judicial a la hora de emitir este tipo de autorizaciones, debe señalarse que la falta de la más mínima concreción legal al respecto ha llevado a la doctrina a plantear la posibilidad de acudir a alguno de los procedimientos ya regulados en la Ley jurisdiccional ${ }^{61}$.

Dicha tarea, sin embargo, no resulta sencilla y está llena de posibles objeciones a plantear.

El procedimiento ordinario no parece que haya sido concebido para la adopción de este tipo de medidas, de carácter claramente sumario y urgente ${ }^{62}$.

rresponder temporalmente a los Juzgados de Guardia, de acuerdo a lo previsto en el artículo 70 de la Ley de Enjuiciamiento Civil y al Reglamento del Consejo General del Poder Judicial. Vid. LO 6/1998 y artículo 8.5 de la LJCA.

60 Vid. Sentencia 210/2013, Rec. 922/2011.

61 Vid. J. M. RoJí BuQueras (2000), El derecho a la inviolabilidad del domicilio y la actuación de los órganos de la Inspección de los Tributos. Un estudio a propósito de la nueva Ley Jurisdiccional 29/1998, de 13 de julio, Impuestos, Ed. La Ley, págs. 34-35.

62 Vid. V. FAIRÉN Guillén (1993), "Algunas ideas básicas sobre la "entrada y registro en domicilio" (del artículo 21 de la ley 1/1992, de protección de la seguridad ciudadana, de 21 de febrero)», Revista de Derecho Procesal, núm. 1, págs. 11-60; J. OlIVÁN DEL CACHO (2011), «La autorización judicial para la entrada en domicilio y restantes lugares cuyo acceso requiera el consentimiento de su titular: aspectos prácticos», Asamblea: Revista Parlamentaria de la Asamblea de Madrid, núm. 25, págs. 197-212; J. E. Peces Morate (1994), «La entrada en el do- 
Tampoco el procedimiento especial para la protección de derechos fundamentales de la persona está pensado para habilitar a la Administración en el ejercicio de sus facultades, que es, como ya hemos dicho, la propia esencia institucional de la autorización de entrada en domicilio.

Por su parte, el procedimiento para la adopción de medidas cautelares exige la tramitación simultánea de un proceso principal, en el que poder insertarse a modo de incidente o pieza separada

En principio, por tanto, la vía más asumible sería acudir a la tramitación que se sigue en el procedimiento abreviado. Ahora bien, al margen de cualquier esfuerzo posibilista que pueda acometerse en este sentido, debe quedar claro que cuando el órgano judicial resuelve una autorización de entrada en domicilio, no ejercita una función jurisdiccional consistente en juzgar y hacer ejecutar lo juzgado ${ }^{63}$.

El Tribunal Constitucional ha señalado que no se trata de un «proceso judicial» en el que se dirime un conflicto entre terceros, ni se resuelve sobre la legalidad y ejecutividad de un acto administrativo ${ }^{64}$.

Se trata de un supuesto o manifestación de lo dispuesto en el artículo 117.4 de la Constitución española, es decir, del ejercicio de funciones judiciales en garantía de un derecho, en este caso, de carácter fundamental ${ }^{65}$.

Según quedó dicho, esa labor del órgano judicial se inserta en el procedimiento administrativo de ejecución forzosa, concibiéndose como un eslabón más de las actuaciones integrantes del expediente abierto al efecto.

Este tipo de procedimientos cuenta, además, con una serie de notas que le atribuyen carácter singular.

Así, la jurisprudencia constitucional no reconoce al titular del derecho la condición de parte, aunque sí de interesado; circunstancia que,

\footnotetext{
micilio o en otros lugares cerrados para la ejecución de actos de la Administración: Hacia un modelo garantista», Jueces para la Democracia, núm. 21, págs. 37-56.

63 Vid. C. ÁlvareZ-LinERA URÍA (1989), «La autorización judicial para la entrada en domicilios particulares, en ejecución de actos administrativos», La Ley: Revista jurídica española de doctrina, jurisprudencia y bibliografía, núm. 1, págs. 1037-1045; J. E. BARRACHINA (2012), «Efectos jurídicos de la entrada en domicilio de la empresa, sin consentimiento del titular», Consell Obert: Recull Informatiu del Consell General de Col-legis de Graduats Socials de Catalunya, núm. 255, págs. 37-42; J. OLIVÁN DEL CACHO (2011), «La autorización judicial para la entrada en domicilio y restantes lugares cuyo acceso requiera el consentimiento de su titular: aspectos prácticos», Asamblea: Revista Parlamentaria de la Asamblea de Madrid, núm. 25, págs. 197-212.

64 Vid. SSTC 139/2004, 137/1985, 50/1995, 171/1997.

65 Vid. J. M. MAcías CASTAÑo (2001), «El desahucio administrativo. La problemática de su ejecución: la entrada en un domicilio y la jurisprudencia constitucional», Seminari.fmc.cat., pág. 14.
} 
sin embargo, encierra una doble contradicción, pues la Ley de la Jurisdicción Contencioso-Administrativa atribuye con carácter general la condición de parte a cuantos tienen interés directo en un asunto y, además, esta misma norma legitima al titular del derecho a impugnar la resolución emitida por el órgano judicial al pronunciarse sobre la solicitud de autorización de entrada, hecha por la Administración Pública ${ }^{66}$.

Otra peculiaridad que presenta este procedimiento es que, según tiene asentado la doctrina judicial, no se requiere necesariamente y en todo caso abrir trámite de audiencia para otorgar la autorización de entra$\mathrm{da}^{67}$. En efecto, tal como indica el Tribunal Superior de Justicia de la Región de Murcia en su Sentencia de 14 de septiembre de $2012^{68}$ :

«En lo que respecta al procedimiento a seguir para la autorización de entrada, no se establece en el artículo 8.6 de la Ley Jurisdiccional. Por tanto, y como ha declarado esta Sala, Secc. 2. ${ }^{\text {a }}$, en sentencia de 19 de diciembre de 2006, “... ninguno de los preceptos que regulan la concesión judicial de estas autorizaciones (art. 8.5 LJ), establecen como requisito previo la concesión de audiencia al interesado, ni que conste que éste se haya opuesto a la entrada (...). Así lo ha puesto de manifiesto la STC 174/93, de 27 de mayo, con cita de los AATC 129/90 y 85/92, cuando señala que el ejercicio de esta función de control, preventivo y prima facie, no requiere que necesariamente y en todo caso el órgano judicial se pronuncie después de conocer los motivos de oposición del interesado, como si se tratase de un proceso, cuando lo cierto es que de lo único que se trata es de apoderar a la Administración para realizar una determinada actuación».

Ahora bien, en el caso de la ejecución forzosa de actos administrativos, esa audiencia viene sugerida por varias razones.

Por un lado, por la propia existencia de un derecho fundamental afectado, cuya protección, lógicamente, exige dotar a las actuaciones practicadas de unas especiales garantías jurídicas.

Además, cabría invocar el carácter contradictorio que preside cualquier intervención de los Tribunales de Justicia.

66 STC 120/2014, de 17 de julio, Rec. 1756/2003; STC 22/2003, de 10 de febrero, Rec. 4400/1999. Al respecto, vid. J. M. RoJí BuQueras (2000), El derecho a la inviolabilidad del domicilio y la actuación de los órganos de la Inspección de los Tributos. Un estudio a propósito de la nueva Ley Jurisdiccional 29/1998, de 13 de julio, Impuestos, Ed. La Ley, pág. 33.

67 Vid. STC 174/1993 y AATC 85/1992 y 129/1990.

68 Vid. Sentencia 672/2012, Rec. 35/2012. 
En último extremo, cabe recordar, igualmente, la necesidad que hay de motivar el auto que debe emitir el órgano judicial, resolviendo la autorización de entrada.

En efecto, la actuación jurisdiccional solo cumplirá la función que le corresponde de garantía de la inviolabilidad del domicilio si, a través de la resolución adoptada, puede comprobarse que se ha efectuado una ponderación de los distintos derechos e intereses que puedan verse afectados y se han tomado las cautelas precisas para que la limitación del derecho fundamental, que la misma comporta, se lleve a cabo del modo menos restrictivo posible.

Ahora bien, también puede ocurrir que, excepcionalmente, la celeridad en la actuación sea incompatible con la demora que implica la audiencia previa del interesado o, incluso, que éste hubiese hecho constar de forma manifiesta su negativa a desalojar el inmueble. Tal como se señala en Sentencia del TSJ de Andalucía de 24 de julio de $2008^{69}$, en esos casos de urgencia, que habrán de ser debidamente justificados por la Administración, podría entenderse que la autorización sea emitida inaudita parte:

«En el presente caso el Juzgado tuvo en cuenta, a la hora de realizar tal ponderación, las circunstancias que constan en el expediente remitido con la solicitud, donde podemos apreciar que el acta previa de ocupación se levantó el 14 de abril de 2004, consignando las cantidades correspondientes y siendo requerido notarialmente el apelante el 24 de mayo de 2007 para que desalojase el inmueble ya que se iba a proceder el 11 de junio a la ocupación de la parcela, oponiéndose el mismo, a través de doña María Rosario, a la ocupación; por lo que, evidentemente, era innecesario el trámite de audiencia para ser oído, pues constaba su negativa por escrito ante el Notario. Añadamos, además, que ninguno de los preceptos que regulan la concesión judicial de estas autorizaciones (art. 8.6 LJ y art. 87.2 LOPJ), establecen como requisito previo la concesión de audiencia al interesado, ni que conste que éste se haya opuesto a la entrada, trámite que por otro lado podría ir en muchos casos en contra de la celeridad exigida por los intereses generales en juego».

69 Vid. Sentencia 709/2008, Rec. 39/2008. 
Asimismo, cabe indicar que pese a las previsiones del artículo 3.3 del Estatuto Orgánico del Ministerio Fiscal en relación con la garantía de los derechos fundamentales, dado que no existe previsión específica al respecto en la Ley jurisdiccional, tampoco se requiere la intervención del Fiscal en este tipo de procedimientos ${ }^{70}$.

Por otro lado, y como ya advertimos, la práctica judicial muestra que, normalmente, los pasos que se siguen al tramitar las autorizaciones de entrada en domicilio no son subsumibles en ninguno de los procedimientos tipo $^{71}$.

Así, el arranque de la tramitación tiene origen en un escrito simple de la Administración autora del acto, que se dirige al juez del domicilio del afectado, interesando la autorización de entrada.

Junto con el mencionado escrito ha de acompañarse el expediente en el que conste el acto administrativo que opera como título de la ejecución forzosa ${ }^{72}$.

Asimismo, debe figurar el previo apercibimiento hecho por la Administración, señalando que vencido el plazo de cumplimiento voluntario se procederá a dar inicio a la ejecución forzosa del acto ${ }^{73}$.

Por último, ha de aportarse el acuerdo ordenando, propiamente, la ejecución forzosa y acreditarse debidamente la notificación de cada uno de los acuerdos mencionados, pues lo contrario, como indica la Sentencia de 1 de marzo de 2012 del TSJ de Madrid ${ }^{74}$, llevaría al interesado a una situación de indefensión y a la consiguiente invalidación de las actuaciones de ejecución forzosa:

«Así las cosas, nos encontramos con la ejecución de acto administrativo que no ha ido precedido ni del necesario requerimiento ni del imprescindible acuerdo ordenando la ejecución forzosa, lo que supone haber

70 Vid. J. M. Macías CASTaño (2001), «El desahucio administrativo. La problemática de su ejecución: la entrada en un domicilio y la jurisprudencia constitucional», Seminari.fmc.cat., pág. 24.

71 Vid. J. F. LóPez de Hontanar SÁnChez (2008), «La autorización de entrada en domicilio para la ejecución de actos administrativos», Estudios Jurídicos, núm. 2008; J. M. MAcíAs CASTAÑo (2001), «El desahucio administrativo: la problemática de su ejecución: la entrada en un domicilio y la jurisprudencia constitucional», Revista Española de Derecho Administrativo, núm. 127, págs. 489-517; M. MARTínez GARcía dE OTAZo (1998), «La autorización judicial para la entrada en el domicilio del deudor de los órganos de la recaudación de la Hacienda Pública: su evolución y requisitos», en La Constitución y la práctica del derecho, coords. Julián Martínez-Simancas SÁnchez y Manuel Aragón Reyes, vol. 3, págs. 2705-2718; A. NavaRRO FAURE (2011), «La entrada en el domicilio de las personas jurídicas y el principio de proporcionalidad», Crónica Tributaria, número extra 1, págs. 39-49.

72 Vid. artículos 58 y 93 de la LRJ-PAC.

73 Vid. artículo 95 LRJ-PAC.

74 Vid. Sentencia 285/2012, de 1 de marzo, del TSJ de Madrid. 
prescindido total y absolutamente del procedimiento legalmente establecido para llevar a cabo la ejecución forzosa de un acto administrativo (artículo 62.1.e) de la Ley 30/1992), que impedía, en buena lógica jurídica, dar lugar a la autorización de entrada solicitada, suponiendo ello la estimación total del recurso de apelación que nos ocupa».

De todo ello se dará traslado al interesado, debiendo ofrecer a éste - y conforme a lo antes indicado_ - trámite de audiencia, antes de que el órgano judicial resuelva mediante auto ${ }^{75}$.

Al margen del iter descrito, debemos significar la particularidad que encierra la solicitud de entrada en domicilio en aquellos casos en los que se ejercitan determinadas potestades públicas exorbitantes, como es el caso de la expropiación forzosa ${ }^{76}$.

La singularidad principal viene dada por el hecho de que la separación entre la fase declarativa y ejecutiva del procedimiento se ve diluida, al tratarse del ejercicio de una potestad eminentemente ablativa.

Ambos momentos se suceden sin solución de continuidad, por lo que surge como cuestión a resolver si ha de emitirse, igualmente, un acto formal de ejecución forzosa antes de solicitar la autorización de entrada $^{77}$.

Los títulos de cobertura son, en este caso, el acta de ocupación y el previo abono o depósito del justiprecio.

Así, el artículo 51 de la Ley de Expropiación Forzosa dispone que hecho efectivo el justiprecio o consignado éste, podrá ocuparse la finca.

A su vez, el artículo 54 de esta misma Ley establece que tras el pago o consignación se extiende el acta de ocupación.

75 En ese trámite, los motivos de oposición que cabe invocar serán, bien la falta de conformidad con la actuación administrativa o, en su caso, la desproporción del medio utilizado por la Administración para la ejecución forzosa del acto administrativo.

76 Vid. M. A. García VAlderRey (2009), «Las autorizaciones judiciales para la entrada del personal de la administración en domicilios particulares», Consultor de los Ayuntamientos y de los Juzgados: Revista técnica especializada en Administración Local y Justicia Municipal, núm. 4, págs. 597-611; L. LAFONT NiCUESA (2006), «La autorización judicial en el orden contencioso-administrativo a las entradas y registros de la Hacienda Pública», Fórum Fiscal de Álava, mes 12, págs. 27-37; V. MANTECA VALDELANDE (2011), «La compulsión sobre las personas como instrumento ejecutivo de la Administración Pública (y 2)», Actualidad Administrativa, núm. 17, pág. 6; P. MoRell Galindo (2003), "La autorización judicial de entrada en el domicilio», Cuadernos de Derecho Local, núm. 2, págs. 100-110; J. OliváN DEL CACHo (2011), «La autorización judicial para la entrada en domicilio y restantes lugares cuyo acceso requiera el consentimiento de su titular: aspectos prácticos», Asamblea: Revista Parlamentaria de la Asamblea de Madrid, núm. 25, 197-212.

77 A favor de la adopción de un acuerdo formal en tal sentido parece mostrarse la Sentencia del TSJ de Madrid de 4 noviembre 2003 (Rec. 58/2003). 
Es, por tanto, dentro de la pieza separada de «pago y toma de posesión» en la que se notifica la fecha en la que ha de desocuparse el bien (art. 53 REF) y se advierte que, si no se abandona voluntariamente éste, se procederá al desalojo forzoso, sin que la Administración tenga que iniciar al efecto ningún otro procedimiento ejecutivo, en caso de verse abocada, finalmente, a tener que solicitar la pertinente autorización judicial de entrada en el domicilio.

Este criterio podemos derivarlo de la Sentencia de 30 de septiembre de 2011 del TSJ de Murcia ${ }^{78}$ :

«Las actas fueron levantadas en la fecha señalada, sin que compareciera la titular expropiada. Por la beneficiaria, "Iberdrola Distribución Eléctrica, S.A.U.” se consignaron los depósitos previos. En fecha 30 de septiembre de 2010 se remitió apercibimiento de ejecución forzosa a la interesada, a fin de que en el plazo de diez días permitiera la ocupación por la beneficiaria. Al ser devuelta por la recurrente la notificación, se practicó por medio de edicto publicado en el BORM de fecha 27 de noviembre de 2010. Se desprende de lo anterior que no puede alegar válidamente la recurrente que no se le notificaron los actos del procedimiento expropiatorio y que no fue apercibida de ejecución forzosa. Por el contrario, consta que no atendió dicho requerimiento por lo que era procedente la autorización de entrada para la efectividad de los actos administrativos, concretamente la ocupación de los terrenos expropiados y ejecución de las obras que motivaron la expropiación, de conformidad con los preceptos de la Ley del Suelo de la Región de Murcia y de la Ley de Expropiación Forzosa que se citan en el auto apelado».

En el mismo sentido se pronuncia el Tribunal Superior de Justicia de Andalucía en su Sentencia de 15 de diciembre de 2008 ${ }^{79}$ :

«En la parte del Decreto del Alcalde relativa al requerimiento de desalojo, ninguna ilegalidad se produce por cuanto está amparado en el citado art. 53 del Reglamen-

78 Vid. Sentencia 882/2011, Rec. 125/2011.

79 Vid. Sentencia 759/2008, Rec. 2419/2000. 
to, y en él se limita a requerir a la entidad titular de los terrenos y edificaciones ya expropiados y a cuyo ocupación tenía derecho la Administración, a que los desaloje, otorgándole un plazo de un mes para que retire la maquinaria del inmueble y lo deje expedito y libre».

\section{El alcance del control a efectuar}

Conforme viene reiterando la jurisprudencia, el juez no concede la autorización de entrada en domicilio «como un mero automatismo formal» 80 .

Ahora bien, el órgano jurisdiccional que ha de pronunciarse sobre dicha solicitud no puede llevar a cabo un examen completo de la actuación administrativa, como haría en un recurso ordinario, sino que solo puede pronunciarse acerca de la apariencia de legalidad que aquélla presenta.

Desde esta perspectiva, el examen que cabe llevar a efecto se asemeja al del fumus boni iuris en las medidas cautelares, en cuyos procedimientos queda vedado al órgano judicial entrar a conocer sobre el fondo del asunto, ni realizar un análisis exhaustivo acerca de la legalidad y proporcionalidad del acto a ejecutar, cuya validez jurídica y eficacia puede discutir el interesado a través del pertinente cauce procesal.

Por esta razón, los extremos que han de ser objeto de examen en el procedimiento de autorización de la entrada en domicilio son estrictos y en cierto modo tasados.

Lo primero que habrá de verificar el órgano judicial es su competencia para conocer del asunto, para lo cual deberá comprobar que el acto que se pretende ejecutar no haya sido recurrido ante otro tribunal y, especialmente, que sus efectos no se encuentren suspendidos, en los términos que ya han quedado examinados.

80 Vid. STC 188/2013, de 4 de noviembre, Rec. 3769/2012; STC 150/2011, de 29 de septiembre, Rec. 5125/2003. En la doctrina, vid. J. E. BARRACHINA (2012), «Entrada de la inspección tributaria en domicilio de persona jurídica: el consentimiento preceptivo», Consell Obert: Recull Informatiu del Consell General de Col-legis de Graduats Socials de Catalunya, núm. 271, págs. 31-35; A. NAVARRo FAure (2011), «La entrada en el domicilio de las personas jurídicas y el principio de proporcionalidad», Crónica Tributaria, número extra 1, págs. 39 49; J. OLIVÁN DEL CACHO (2011), «La autorización judicial para la entrada en domicilio y restantes lugares cuyo acceso requiera el consentimiento de su titular: aspectos prácticos», Asamblea: Revista Parlamentaria de la Asamblea de Madrid, núm. 25, págs. 197-212; J. E. PECES MoRATE (1994), «La entrada en el domicilio o en otros lugares cerrados para la ejecución de actos de la Administración: Hacia un modelo garantista», en Jueces para la Democracia, núm. 21, págs. 37-56. 
En segundo lugar, deberá contrastarse que el interesado sea efectivamente el titular del espacio físico para cuya entrada se solicita la autorización, así como que este último constituye, en realidad, un domicilio constitucionalmente protegido o cualquier otro espacio al que se haya extendido legalmente esa misma garantía jurídica.

Concurriendo esos presupuestos previos, el órgano judicial encargado de resolver sobre la autorización de entrada en domicilio debe realizar un análisis valorativo, tanto sobre el acto que sirve de cobertura como sobre el mismo procedimiento de ejecución forzosa ${ }^{81}$.

Ambos deben aparecer fundados en derecho, prima facie, por lo que el examen a realizar debe ceñirse a comprobar si existen infracciones evidentes —esto es, graves y manifiestas — en la tramitación de ambos expedientes.

A tal efecto, deberá evidenciarse que esos actos fueron dictados por el órgano competente de una Administración habilitada, y previa tramitación de un procedimiento con apariencia de legalidad, pues, tal como indica la Sentencia del TSJ de Madrid de 7 de marzo de $2012^{82}$ :

«La preceptiva autorización judicial para la entrada en domicilio y demás lugares que requieran el consentimiento previo del titular, como limitación al principio de autotutela administrativa, tiene como único fundamento la protección del derecho a la intimidad proclamado en el art. 18.1 CE, quedando circunscrita la actuación judicial a examinar la regularidad formal del procedimiento del que dimana la Resolución para cuya ejecución forzosa se insta la autorización — sin valoración alguna de fondo-y la competencia del órgano que la dicta».

81 Vid. M. Martínez García de OTAzo (1998), «La autorización judicial para la entrada en el domicilio del deudor de los órganos de la recaudación de la Hacienda Pública: su evolución y requisitos", en La Constitución y la práctica del derecho, coords. Julián MARTínEZSimancas SÁNCHEZ y Manuel ARAgón Reyes, vol. 3, ISBN 84-85533-56-9, págs. 2705-2718; P. Morell Galindo (2003), «La autorización judicial de entrada en el domicilio», Cuadernos de Derecho Local, núm. 2, págs. 100-110; A. NAvarro Faure (2011), "La entrada en el domicilio de las personas jurídicas y el principio de proporcionalidad», Crónica Tributaria, número extra 1, págs. 39-49; J. OLIVÁN DEL CACHO (2011), «La autorización judicial para la entrada en domicilio y restantes lugares cuyo acceso requiera el consentimiento de su titular: aspectos prácticos», Asamblea: Revista Parlamentaria de la Asamblea de Madrid, núm. 25, págs. 197-212; J. L. RASCÓN ORTEGA (2000), «La entrada y registro como límite al derecho a la inviolabilidad del domicilio", Estudios Jurídicos. Cuerpo de Secretarios Judiciales, núm. 1 (ejemplar dedicado a «Actuaciones del Juzgado de Guardia en relación con los Derechos Fundamentales. Catástrofes y emergencias: respuesta de la Administración de Justicia. Protección de datos jurídicos»), págs. 241-278.

82 Vid. Sentencia 171/2012, Rec. 1228/2011. 
Asimismo, con carácter general, durante la sustanciación de ambos procedimientos debió haberse dado audiencia al interesado, de modo que éste tuviera la oportunidad real de conocer la existencia de los actos emitidos y la posibilidad de cumplir de forma voluntaria con el contenido de los mismos.

Consecuentemente, y como advierte la Sentencia de 12 de febrero de 2000 del TSJ de Cantabria ${ }^{83}$, además de existir un acto administrativo que sirva de título y reúna los requisitos señalados, es necesaria la regularidad del procedimiento de ejecución forzosa y la existencia de una línea directa de continuación entre ambos; extremo que, por otra parte, determina la imposibilidad de recurso en vía de ejecución, salvo que se acredite que la actuación de materialización del acto administrativo excede su contenido, quebrando dicha continuidad ${ }^{84}$ :

«La excepción de acto firme y consentido es frecuentemente invocada con motivo de la impugnación jurisdiccional de un procedimiento de ejecución forzosa cuando, como sucede ahora, el actor o actores no recurrieron en su día el acto administrativo objeto de la ejecución. En tales casos, es jurisprudencia reiterada del Tribunal Supremo que no cabe el recurso contencioso contra los actos de ejecución a menos que, y la excepción es importante, los segundos incurran en vicios autónomos de legalidad e independientes de cualesquiera otros que pudieran aquejar al acto originario que se consintió (así, por ejemplo, la sentencia del Tribunal Supremo de 29 Jul. 1986). Ello significa que la excepción de acto firme y consentido no opera de manera automática, sino que entrará en juego y deberá ser apreciada cuando la ejecución forzosa se sitúe en línea directa de ejecución del acto administrativo y, por ello mismo, no incorpore vicios propios».

Verificado lo anterior, la intervención del órgano judicial debe centrarse en realizar un control de proporcionalidad e idoneidad sobre la medida a autorizar ${ }^{85}$.

83 Vid. Rec. 1539/1998.

84 Vid. M. Lafuente Benaches (2015), «La protección de la vivienda frente a la potestad administrativa de ejecución forzosa con entrada domiciliaria», Revista Española de Derecho Administrativo, enero-marzo, pág. 75. Cit. F. SAINZ MoRENo (1977), «Sobre la ejecución en línea directa de continuación del acto y otros principios de la coacción admininstrativa. Sentencia de la Sala 4. ${ }^{a}$ del Tribunal Supremo de 15 de febrero de 1977. Ponente: D. Paulino Martín», Revista Española de Derecho Administrativo, núm. 13, pág 32.

85 Vid. V. FAIRÉn GuILlén (1993), «Algunas ideas básicas sobre la "entrada y registro en domicilio" (del artículo 21 de la ley 1/1992, de protección de la seguridad ciudadana, de 21 
En esa ponderación de intereses a realizar por el juez, solo extraordinariamente se ha considerado la entrada para el desalojo y privación de la vivienda como un sacrificio desorbitado para el fin de la ejecución del acto administrativo desatendido; si bien no deja de haber pronunciamientos que deniegan la entrada domiciliaria requerida, anteponiendo al interés implícito en la ejecución forzosa del acto el propio interés particular del titular del domicilio ${ }^{86}$.

A efectos de realizar dicha ponderación de intereses, lo primero que se ha de comprobar es la legitimidad del fin perseguido por la Administración a través del acto que pretende ejecutar.

Para ello ha de verificarse la idoneidad de la medida, esto es, que el acto que se pretende ejecutar requiere efectivamente la entrada en domicilio, como una necesidad directa, que emana de su propio contenido material.

Deberá comprobarse igualmente si dicha intervención resulta imprescindible, es decir, si se han agotado los demás medios para la ejecución forzosa del acto.

De esta forma, siendo varios los medios admisibles, deberá optarse por el menos restrictivo para la libertad individual.

Así, por ejemplo, la Ley de Patrimonio de las Administraciones Públicas plantea la posibilidad de acudir a dos medios distintos de ejecución forzosa: la multa coercitiva y la compulsión sobre las personas (art. 59.4), lo que determina que en los casos de desahucio administrativo regulados en esa Ley, la autorización de entrada en domicilio presente un carácter más residual ${ }^{87}$.

Finalmente, habrá de garantizarse que la irrupción en el domicilio del interesado no produce más limitaciones a la intimidad que aquellas que sean estrictamente indispensables.

de febrero)», Revista de Derecho Procesal, núm. 1, págs. 11-60; J. FERNÁNDEZ-CorREdor SÁNCHEz-DiezMa (2009), «Entrada a domicilio. Medida administrativa», CEFLegal: Revista Práctica de Derecho. Comentarios y casos prácticos, núm. 103, pág. 175; A. Frías LóPez (2000), «Las autorizaciones judiciales de entrada en domicilio", Revista Jurídica de la Comunidad de Madrid, núm. 6, págs. 29-64; L. LAFONT NicuESA (2006), «La autorización judicial en el orden contencioso-administrativo a las entradas y registros de la Hacienda Pública», Fórum Fiscal de Álava, mes 12, págs. 27-37.

86 Vid. M. LAFuente Benaches (2015), «La protección de la vivienda frente a la potestad administrativa de ejecución forzosa con entrada domiciliaria», Revista Española de Derecho Administrativo, enero-marzo, pág. 80. Cit. Sentencia del TSJ de Madrid de 17 de marzo de 2009.

87 Vid. M. A. Ruiz López (2011), «Autorización judicial de entrada en el domicilio y potestades administrativas: extensión del ámbito protegido, cuestiones procedimentales y proporcionalidad», Revista de Estudios de la Administración Local y Autonómica, núm. 317, pág. 231. 
Este último control conduce a que el auto que ha de resolver la solicitud de entrada en domicilio pueda limitar la duración de esa intervención y fijar las condiciones en las que debe producirse ésta; resultando en último extremo imprescindible que la Administración responsable de la ejecución del acto dé cuenta al juez del resultado de dicha entrada una vez producida ésta ${ }^{88}$.

En cualquier caso, cabe concluir insistiendo en que el juicio de proporcionalidad que puede realizar el órgano judicial en este tipo de procedimientos se refiere a la relación existente entre el derecho a la inviolabilidad del domicilio y la forma de ejecución del acto administrativo que implica la entrada en el domicilio del interesado.

$\mathrm{Al}$ respecto, cabe traer a este lugar lo señalado en el Auto de 4 de febrero de 2015 del JCA núm. 1 de Santander ${ }^{89}$ :

«Superado el control de la apariencia de legalidad del acto y de su ejecutividad, así como los juicios de adecuación y necesidad, el estricto juicio de proporcionalidad, más que sobre la entrada domiciliaria en sí, ha de proyectarse sobre la forma y circunstancias de la misma. Son esas formas y circunstancias, en el marco de la garantía de la mínima restricción de la privacidad que subyace al derecho a la inviolabilidad del domicilio, las que han de valorarse fundamentalmente desde la perspectiva del juicio estricto de proporcionalidad».

Así pues, el juicio de proporcionalidad que debe llevar a cabo el órgano judicial no puede referirse a la relación existente entre el contenido del acto administrativo que sirve de título de ejecución y los derechos o intereses que dicho acto administrativo haya podido sacrificar o limitar.

Esto es, la comprobación que ha de realizar el juzgador lo es en garantía exclusiva del derecho a la inviolabilidad del domicilio, no para la garantía de otros posibles derechos en los que el propio acto a ejecutar pudiera incidir, de una forma directa o indirecta.

88 Vid. M. A. GARcía VALdERREy (2007), «La autorización judicial para la entrada en el domicilio en la ejecución de las órdenes de ejecución», Práctica Urbanística: Revista Mensual de Urbanismo, núm. 63, págs. 8-16; M. A. GARCÍA VALDERREY (2009), «Las autorizaciones judiciales para la entrada del personal de la administración en domicilios particulares», Consultor de los Ayuntamientos y de los Juzgados: Revista técnica especializada en Administración Local y Justicia Municipal, núm. 4, págs. 597-611; P. J. Maldonado Canito (2012), «Procedimiento de solicitud de entrada en domicilio en fase administrativa y jurisdiccional», Iuris: Actualidad y Práctica del Derecho, núm. 171, págs. 52-59.

89 Vid. Rec. 390/2014. 
En este sentido, y en relación con la garantía de la indemnidad patrimonial del sujeto expropiado, la Sentencia del TSJ de Madrid de 7 de marzo de $2012^{90}$ recuerda cómo la pendencia de un recurso contra el justiprecio resulta ajena a la obligación de desalojo y, por tanto, no interfiere, en modo alguno, en la autorización de entrada en domicilio:

«Dicho cuanto antecede, es claro que procede, con estimación del recurso de apelación, autorizar la entrada indebidamente denegada, sin que pueda compartirse la razón fundamentadora de la decisión del Juzgado y que no es otra que la pendencia del precitado recurso contra el justiprecio, algo ajeno a la obligación de desalojo que pesa sobre el apelado y que no interfiere en el otorgamiento de la autorización solicitada al darse los presupuestos legalmente exigidos al efecto, huérfanos de cualquier valoración de fondo, algo que le está vedado a la hora de adoptar una decisión de esta naturaleza».

Lo mismo ocurriría, por ejemplo, con una posible alegación relativa a la pretensión de realojo del sujeto afectado por una actuación urbanística, pues ésta tampoco podría ser examinada en este procedimiento judicial, tal como nos indica la Sentencia 4 de noviembre de 2003 del TSJ de Andalucía ${ }^{91}$ :

«Concurre la necesaria apariencia de legalidad del acto administrativo cuya ejecución se pretende por la Administración (resolución de fecha 21 de noviembre de 2002 y de fecha 9 de enero de 2003, de apercibimiento de ejecución forzosa), circunstancia no desvirtuada por las alegaciones de la parte demandada que se refieren exclusivamente a su derecho al realojo que en todo caso hacen referencia al fondo de su pretensión, que no puede ser examinada en este procedimiento concreto».

$\mathrm{Al}$ respecto, procede recordar que, aun tratándose de un derecho fundamental, la inviolabilidad del domicilio no tiene carácter ilimitado, tal como, en la práctica, ha pretendido ver en él un sector de la doctrina,

90 Vid. Sentencia 171/2012, Rec. 1228/2011.

91 Vid. Sentencia 70/2003, Rec. 58/2003. 
que vincula el mismo con otras garantías constitucionales, como es la protección a la vivienda ${ }^{92}$.

\section{El recurso contra el auto judicial y la ejecutividad del acto adminis- trativo}

Para concluir este estudio, debemos referirnos en último término a los efectos que la eventual impugnación de la resolución judicial que autoriza la entrada en domicilio puede producir en el ulterior desenvolvimiento de la autotutela administrativa.

A este respecto, debemos recordar que, conforme establece el artículo 80.1.d) de la Ley jurisdiccional, los autos recaídos sobre las autorizaciones previstas en el artículo 8.5 de esta misma norma son apelables en un solo efecto.

Consecuentemente, y según recuerda, entre otras, la Sentencia de 16 de julio de $2014^{93}$ del TSJ de la Comunidad Valenciana, este recurso no tiene efectos suspensivos:

«Por último, la apelante solicita también en su escrito de interposición del presente recurso de apelación que se acuerda por la Sala la suspensión de los efectos del auto de 22 de noviembre de 2013 recurrido. Dicha petición no puede ser acogida a tenor del art. 80.1 de la Ley 29/1998, precepto legal en cuya virtud ese auto es apelable en un solo efecto, de manera que el presente recurso carece de efectos suspensivos de la resolución judicial impugnada».

Por tanto, la Administración actuante podrá proceder a entrada en domicilio sin necesidad de esperar a la firmeza del auto judicial emitido, pues como advierte, a su vez, el TSJ de Andalucía en Sentencia de 18 de mayo de $2007^{94}$ :

92 Vid. M. Lafuente Benaches (2015): «La protección de la vivienda frente a la potestad administrativa de ejecución forzosa con entrada domiciliaria», Revista Española de Derecho Administrativo, enero-marzo, pág. 67-91.

93 Vid. Sentencia 744/2014, de 16 de julio (Rec. 182/2014).

94 Vid. Sentencia 1159/2007, Rec. 85/2007. En la doctrina, vid. J. E. BARRACHINA (2010), «Efectos jurídicos de la entrada en domicilio de la empresa, sin consentimiento del titular», Consell Obert: Recull Informatiu del Consell General de Col-legis de Graduats Socials de Catalunya, núm. 255, págs. 37-42; ibidem (2012), «Entrada de la inspección tributaria en domicilio de persona jurídica: el consentimiento preceptivo", Consell Obert: Recull Informatiu del Consell General de Col-legis de Graduats Socials de Catalunya, núm. 271, págs. 31-35; 
«Es claro que si aquella otra persona ocupante de la vivienda se vio de alguna forma afectada negativamente en la esfera de sus intereses, sólo a ella correspondía alegar dicha situación e instar las acciones administrativas o judiciales procedentes, sin que, consecuentemente, pueda admitirse al apelante la alegación de una situación como aquélla, que le es ajena, sin que, finalmente, sea cuestionable tampoco la posibilidad de ejecución inmediata de la medida por razón de la pendencia del presente recurso, que, según el artículo 80.1 LJCA, era apelable en un solo efecto».

La única incertidumbre que cabe plantear es si debe reiterarse el anuncio de ejecución forzosa del acto administrativo, indicando al interesado la fecha en la que está prevista la entrada ${ }^{95}$.

A nuestro juicio, esa nueva comunicación constituiría una mera liberalidad de la Administración Pública ejecutante, la cual ya estaría investida para efectuar la intervención en el domicilio del interesado, sin guardar otra formalidad al efecto que las que el propio órgano judicial hubiese establecido, en aras a la proporcionalidad antes referida.

Igualmente, cabe señalar que no es necesario, ni procedente, solicitar la ejecución provisional del auto ${ }^{96}$. Al respecto también existe una doctrina judicial uniforme, de la que es expresiva la Sentencia de 18 de mayo de 2012 del Tribunal Superior de Justicia de Castilla y León ${ }^{97}$ :

«Ello no significaba que se suspendiera la efectividad del Auto de 30 de enero de 2012, dado que expresamente se indica en el artículo 80.1.d) de la Ley Jurisdiccional que son apelables en un solo efecto los autos recaídos so-

\footnotetext{
J. F. LÓPEZ de Hontanar SÁNChez (2008), «La autorización de entrada en domicilio para la ejecución de actos administrativos», Estudios Jurídicos, núm. 2008; J. M. MACíAS CASTAÑo (2001), «El desahucio administrativo: la problemática de su ejecución: la entrada en un domicilio y la jurisprudencia constitucional», Revista Española de Derecho Administrativo, núm. 127, págs. 489-517.

95 Vid. J. Oliván del CACHo (2011), «La autorización judicial para la entrada en domicilio y restantes lugares cuyo acceso requiera el consentimiento de su titular: aspectos prácticos», Asamblea: Revista Parlamentaria de la Asamblea de Madrid, núm. 25, págs. 197-212.

96 Al respecto, vid. igualmente C. ÁlVAREZ-LINERA URÍA (1989), «La autorización judicial para la entrada en domicilios particulares, en ejecución de actos administrativos», La Ley: Revista jurídica española de doctrina, jurisprudencia y bibliografía, núm. 1, págs. 1037-1045; V. Manteca Valdelande (2011), «La compulsión sobre las personas como instrumento ejecutivo de la Administración Pública (y 2)», Actualidad Administrativa, núm. 17, pág. 6.

97 Vid. Sentencia 266/2012, Rec. 104/2012.
} 
bre las autorizaciones previstas en el art. 8.6, por lo que si es en un solo efecto, ello supone que es en el devolutivo, pero no suspensivo de la eficacia de la resolución, sin que se haya procedido en contra de los artículos indicados por el recurrente, artículo 84.3 y 4 , por cuanto los mismos se refieren al supuesto de ejecución provisional de la sentencia, que no es este el caso que nos ocupa, dado que estamos ante un Auto de autorización de entrada, donde existe la previsión específica de que la apelación es en un solo efecto, en el artículo 80.1.d)».

Finalmente, tampoco cabría abrir un incidente de ejecución del artículo 109 de la Ley jurisdiccional, resultando concluyente en este punto el ya citado Auto de 4 de febrero de 2015 del JCA núm. 1 de Santander ${ }^{98}$, en el que se dice así:

«La parte solicita la incoación de incidente del art. 109 de LJCA, pero confunde el sentido y naturaleza del procedimiento del art. 8.6 LJCA. Este procedimiento, como excepción al principio de autotutela ejecutiva, implica la intervención del Juez pero en un expediente de la administración local que ordena un desahucio administrativo (autotutela declarativa). Y en virtud de sus prerrogativas y potestades no necesita acudir a la tutela judicial. Lo que sucede es que esa autotutela afecta al ámbito de un derecho fundamental y por ello se impone el control preventivo por un juez, pero de una potestad administrativa. Aquí no hay una orden judicial de desahucio o desalojo. Es el Ayuntamiento el que, en uso de sus potestades, lo declara y ejecuta. Y por ello, no hay una resolución judicial que pueda o no ejecutarse. El Auto dictado es sólo una autorización para entrar en un domicilio a efectos de que el Ayuntamiento cumpla su acto, nada más. No es título que lleva aparejada ejecución ni da lugar a un procedimiento de ejecución forzosa judicial».

En efecto, tal como ya ha quedado señalado, no estamos ante la ejecución de una resolución judicial, sino ante una actuación administrativa que ha obtenido la homologación judicial para seguir adelante.

98 Vid. Rec. 390/2014. 
La única posibilidad, por tanto, de paralizar los efectos de la resolución judicial emitida es instar y obtener la adopción de una medida cautelar de suspensión frente al acto administrativo que se pretende ejecutar.

\section{CONCLUSIONES}

Todo lo señalado hasta aquí nos permite describir el régimen jurídico aplicable al control judicial de la entrada en domicilios, a partir de las siguientes conclusiones:

1. La escasa regulación existente sobre la institución analizada genera importantes lagunas en su aplicación, que no son acordes, en absoluto, al grado de protección constitucional atribuida a la garantía de la inviolabilidad del domicilio, que subyace a esta figura. De todos modos, aun tratándose de un derecho fundamental, su alcance no es ilimitado, tal como, en la práctica, ha pretendido ver en él un sector de la doctrina que cohonesta este derecho con otras garantías constitucionales, en particular con la protección de la vivienda.

2. La existencia de un domicilio constitucionalmente protegido podrá darse siempre que nos encontremos ante un lugar separado del entorno físico exterior de forma inequívoca, en el que la persona pueda actuar sin intromisión de terceros. La aptitud de ese espacio para desarrollar en él la vida privada, sus signos externos y el uso o destino dados a éste, constituyen elementos esenciales para la delimitación de ese bien jurídico, objeto de tutela constitucional.

3. El derecho a la inviolabilidad del domicilio se presenta como una garantía jurídica que resiste ante la quiebra del título patrimonial sobre el bien físico o frente a la propia tolerancia del legítimo dueño de éste. La manifestación más evidente la encontramos en el caso de las expropiaciones. El titular del inmueble, una vez abonado o depositado el justiprecio y tras levantarse el acta de ocupación, ya no ostenta ningún derecho sobre el bien, real ni posesorio; sin embargo, ello no excluye que, ante una eventual oposición del sujeto expropiado, se precise autorización judicial para la entrada en domicilio.

4. El consentimiento que cabe recabar del titular del domicilio, con el fin de enervar la autorización judicial de entrada, debe ser inequívoco, aunque no necesariamente ha de ser expreso, ni tiene por qué prestarse por escrito. Dicho consentimiento no podrá estar viciado por error, violencia o intimidación de ninguna clase. Además, el consentimiento 
ha de ser emitido por persona mayor de edad, que se encuentra en condiciones de manifestar libremente su voluntad, y cuando existe pluralidad de titulares habrá de primar la prohibición de entrada que oponga una de esas personas, frente al consentimiento que otorguen las demás.

5. En los casos de estado de necesidad, la Ley Orgánica aplicable limita la facultad de entrada en domicilio a las Fuerzas y Cuerpos de Seguridad. Esta circunstancias y la falta de una previsión análoga en otras normas sectoriales dejan sin cobertura directa la acción de otros cuerpos de intervención en este tipo de situaciones de extrema y urgente necesidad, como es el caso de los servicios de extinción de incendios o los equipos de protección civil.

6. Fuera de los supuestos de obtención del consentimiento del titular, delito flagrante o estado de necesidad, la entrada en domicilio exige contar con la pertinente resolución judicial. Dicha intervención se traduce en un acto de autorización que levanta un obstáculo para el ejercicio de una potestad administrativa, insertándose en el procedimiento como un trámite más a modo de refuerzo de la protección de los derechos y libertades públicos. En definitiva, se viene a apoderar a la Administración Pública para realizar una determinada actuación en garantía de un bien jurídico prevalente.

7. La situación jurídica del acto a ejecutar constituye uno de los elementos básicos para la autorización judicial de la entrada en domicilio, erigiéndose, además, con frecuencia, en la clave de estrategias procesales que nada tienen que ver con la inviolabilidad domiciliaria y que causan un notable perjuicio al interés general que tutela la Administración Pública. En cualquier caso, siempre que un acto administrativo es recurrido y se encuentra pendiente de resolución sobre la suspensión de su eficacia, la Administración no puede proceder a su ejecución forzosa ya que impediría la obtención de la tutela judicial efectiva. En estos casos, solo el órgano que deba conocer de la suspensión será también el competente para resolver sobre la autorización de entrada, impidiéndose así la interferencia que el «juez de garantías» podría llegar a producir en la acción del «juez del proceso».

8. La confirmación por el órgano judicial del acto que implica la entrada en domicilio excluye la necesidad de obtener una autorización posterior para llevar a cabo la misma; no obstante, a tal fin es preciso que la entrada suponga una «ejecución en línea directa o de continuidad» con el acto confirmado al llevar implícita la entrada en domicilio. En caso contrario la autorización seguirá siendo necesaria, aunque el juez que deba pronunciarse al respecto no realizará una nueva revi- 
sión de la validez del acto a ejecutar, sino de los extremos relacionados con la específica función de garantía que tiene atribuida constitucionalmente.

9. La explicación a las peculiaridades que presenta el procedimiento de autorización de entrada debe encontrarse en la verdadera naturaleza de esa intervención, que no determina la apertura de un "proceso judicial» en el que se dirime un conflicto entre terceros, ni se resuelve sobre la legalidad y ejecutividad de un acto administrativo. Se trata de un supuesto o manifestación de lo dispuesto en el artículo 117.4 de la Constitución española, es decir, del ejercicio de funciones judiciales en garantía de un derecho, en este caso, de carácter fundamental. Según quedó dicho, esa labor del órgano judicial se inserta en el procedimiento administrativo de ejecución forzosa, concibiéndose como un eslabón más de las actuaciones integrantes del expediente incoado al efecto.

10. El Tribunal Constitucional no atribuye al titular del derecho la condición de parte en el procedimiento de autorización de entrada, aunque sí de interesado. Esta circunstancia, sin embargo, encierra una cierta contradicción jurídica, pues la Ley de la Jurisdicción Contencioso-Administrativa otorga legitimación a cuantos tienen interés directo en un asunto. Asimismo, según tiene asentado la doctrina judicial, no se requiere necesariamente y en todo caso abrir trámite de audiencia para otorgar la autorización de entrada. Ahora bien, en el caso de la ejecución forzosa de actos administrativos, esa audiencia viene sugerida por varias razones. La primera de ellas es la propia existencia de un derecho fundamental afectado. En segundo lugar, cabría invocar el carácter contradictorio que preside cualquier actuación judicial. En último extremo, cabe recordar, igualmente, el carácter motivado que ha de tener el auto que ha de emitir el órgano judicial, resolviendo la autorización de entrada.

11. Particular relevancia encierra la solicitud de entrada en domicilio en aquellos casos en los que se ejercitan determinadas potestades públicas exorbitantes, como es el caso de la expropiación forzosa. La singularidad principal viene dada por el hecho de que la separación entre el procedimiento declarativo y el de ejecución forzosa se ve diluida, al tratarse de una potestad eminentemente ablativa. Es, por tanto, dentro de la pieza separada de "pago y toma de posesión» en la que se notifica la fecha en la que ha de desocuparse el bien y se advierte que si no se abandona voluntariamente éste, se procederá a la ejecución forzosa del desalojo. De no facilitarse la entrada en el plazo mínimo otorgado, se abre la posibilidad de solicitar directamente la autorización ju- 
dicial de entrada. En estos casos, la pendencia de un recurso contra el justiprecio resulta ajena a la obligación de desalojo y no interfiere en la autorización de entrada en domicilio. Lo mismo ocurriría con cualquier alegación relativa al realojo, que no podría ser examinada en este procedimiento concreto.

12. El juez de la autorización de entrada «no es el juez de la legalidad», por lo que no puede llevar a cabo un examen completo de la actuación administrativa, como haría en un recurso ordinario, sino solo de su apariencia. Esto es, no puede adentrarse el órgano judicial en un examen exhaustivo acerca de la legalidad y proporcionalidad del acto a ejecutar, cuya validez jurídica y eficacia puede discutir el interesado a través del pertinente cauce procesal. Dicho examen se asemeja al del fumus boni iuris en las medidas cautelares, en cuyo procedimiento queda vedado al órgano judicial entrar a conocer sobre el fondo del asunto.

13. Lo que debe realizar el órgano judicial encargado de resolver sobre la autorización de entrada en domicilio es un análisis valorativo, tanto sobre el acto que sirve de cobertura como sobre el mismo procedimiento de ejecución forzosa. Ambos deben aparecer fundados en derecho, prima facie, por lo que debe limitarse a comprobar si existen infracciones evidentes, esto es, graves y manifiestas, en la tramitación de ambos expedientes. A tal efecto, debe evidenciarse que estos actos fueron dictados por una Administración habilitada y por órgano competente, previa tramitación de un procedimiento con apariencia de legalidad.

14. Verificado lo anterior, la intervención del órgano judicial debe centrarse en realizar un control de proporcionalidad e idoneidad sobre la medida a autorizar. En este punto, lo primero que ha de comprobar es la legitimidad del fin perseguido. Para ello deberá acreditarse la idoneidad de la medida, esto es, que el acto que se pretende ejecutar requiere efectivamente la entrada en domicilio. Deberá comprobar igualmente si dicha intervención resulta imprescindible, es decir, si se han agotado los demás medios para la ejecución forzosa del acto. Finalmente, habrá de garantizar que la irrupción en el domicilio del interesado no produce más limitaciones a la intimidad que aquellas que sean estrictamente indispensables.

15. En relación a este último punto procede salir al paso de opiniones doctrinales recientemente vertidas, debiendo concluirse que el juicio de proporcionalidad que puede realizar el órgano judicial en este tipo de procedimientos se refiere a la relación existente entre el derecho a la inviolabilidad del domicilio y la forma de ejecución del acto 
administrativo que implica la entrada en el domicilio del interesado. Consiguientemente, ese juicio de proporcionalidad no puede referirse a la relación existente entre el contenido del acto administrativo que sirve de título de ejecución y los derechos o intereses que dicho acto administrativo haya podido sacrificar o limitar. Esto es, el juicio de proporcionalidad que ha de llevar a efecto el órgano judicial lo es en garantía exclusiva del derecho a la inviolabilidad del domicilio, no para la garantía de otros posibles derechos en los que el propio acto a ejecutar puede incidir. 
